Discussion Paper No. 09-051

How Does EU Cohesion Policy Work?

Evaluating its Effects on Fiscal Outcome Variables

Tobias Hagen and Philipp Mohl

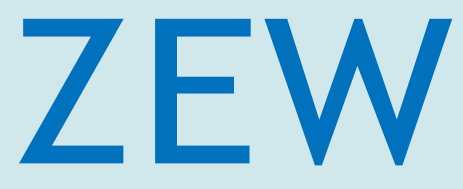

Zentrum für Europäische Wirtschaftsforschung $\mathrm{GmbH}$

Centre for European

Economic Research 
Discussion Paper No. 09-051

\section{How Does EU Cohesion Policy Work? Evaluating its Effects on Fiscal Outcome Variables}

Tobias Hagen and Philipp Mohl

Download this ZEW Discussion Paper from our ftp server:

ftp://ftp.zew.de/pub/zew-docs/dp/dp09051.pdf

Die Discussion Papers dienen einer möglichst schnellen Verbreitung von neueren Forschungsarbeiten des ZEW. Die Beiträge liegen in alleiniger Verantwortung der Autoren und stellen nicht notwendigerweise die Meinung des ZEW dar.

Discussion Papers are intended to make results of ZEW research promptly available to other economists in order to encourage discussion and suggestions for revisions. The authors are solely responsible for the contents which do not necessarily represent the opinion of the ZEW. 


\section{Non-technical summary}

The impact of the EU Cohesion Policy has mainly been evaluated by analysing its growth effects. However, this perspective neglects that the EU support might affect other policy fields as well.

There are at least two reasons why the impact on public investment should be of special interest. First of all, according to the principle of additionality the Member States have to co-finance EU-funded projects but must not crowd out spending for national public investments elsewhere. Second, since a major part of Cohesion Policy payments is spent on government investments, virtually all empirical studies on the investigation of the growth effects assume that the Cohesion Policy increases investments leading to a higher steady-state capital stock per capita, which, in turn, increases the GDP growth rate. Hence, an essential condition for the effectiveness of EU transfers is the degree to which they affect overall national public investments. However, the impact of Cohesion Policy payments on national public investments has not yet been evaluated.

Furthermore, instead of increasing future-orientated spending, EU Cohesion Policy payments may (indirectly) be used to reduce public deficits. This is possible if EU regional policy crowds out national spending, which is most likely to occur in poorer countries. To the best of our knowledge, there has been no paper investigating the effects on public deficits.

Against this background, the paper at hand examines through which channels this policy field works by analysing the impact of EU Cohesion Policy payments on national public investments and primary budget balances. In doing so, we use a comprehensive dataset of $27 \mathrm{EU}$ countries, extend the time period of investigation to 1982-2006 and apply advanced panel econometric methods.

Our results indicate that EU Cohesion Policy payments do not significantly increase national public investments, thus pointing to a crowding out of national spending. Moreover, the hypothesis that EU funds are used for the consolidation of public budgets cannot be rejected in all econometric specifications. 


\section{Zusammenfassung}

Bisher wurde die Kohäsionspolitik der Europäischen Union (EU) nahezu ausschließlich im Hinblick auf ihre Wachstumswirkungen untersucht. Diese Fokussierung vernachlässigt, dass die EU Kohäsionspolitik ebenfalls auf andere Politikfelder einwirken kann.

Es gibt mindestens zwei Gründe weshalb der Einfluss auf öffentliche Investitionen von besonderem Interesse ist. Erstens müssen die EU Mitgliedstaaten die von der EU geförderten Projekte kofinanzieren, wobei diese Förderung gemäß dem Additionalitätsprinzip die staatlichen Investitionen nicht verdrängen darf. Zweitens wird ein Großteil der Kohäsionspolitik im Bereich staatlicher Investitionen (wie bspw. Verkehrsinfrastruktur) ausgegeben. Daher basieren nahezu alle Studien, welche die Wachstumswirkungen der EU Kohäsionspolitik untersuchen, auf der Annahme, dass die Kohäsionspolitik die Investitionen erhöht, die wiederum im Steady State zu einem höheren Kapitalstock pro Kopf führen und somit die Wachstumsrate des BIP beeinflussen. Folglich ist eine notwendige Bedingung für die Wirksamkeit der EU Transfers, dass sie die gesamten öffentlichen Investitionen erhöhen. Jedoch wurde der Einfluss der EU Kohäsionspolitik auf die staatlichen Investitionen bisher nicht evaluiert.

Darüber hinaus könnte es sein, dass die EU Kohäsionspolitikzahlungen statt zur Erhöhung der Investitionen (indirekt) dazu verwendet werden, die öffentlichen Haushaltsdefizite zu verringern. Dies ist möglich, sofern die EU Kohäsionspolitik nationale Ausgaben verdrängt, was insbesondere im Falle ärmerer Mitgliedsstaaten (und den Zahlungen aus dem so genannten Kohäsionsfonds) denkbar ist. Unseres Wissens gibt es bisher keine Studie, welche die Wirkungen der Kohäsionspolitik auf die öffentlichen Haushalte untersucht.

Vor diesem Hintergrund ist es das Ziel dieser Studie, den Einfluss der Zahlungen der EU Kohäsionspolitik auf die öffentlichen Investitionen sowie die Haushaltsdefizite zu analysieren. Hierzu wird ein umfassender Datensatz von 27 EU Ländern verwendet, die Untersuchungsperiode auf den Zeitraum 1982-2006 ausgedehnt und panelökonometrische Methoden angewendet.

Unsere Ergebnisse zeigen, dass die EU Kohäsionspolitik die öffentlichen Investitionen nicht signifikant erhöht, was auf eine Verdrängung nationaler Ausgaben hindeutet. Darüber hinaus kann die Hypothese, dass die EU Förderung zur Konsolidierung der öffentlichen Haushalte verwendet wird, nicht in allen ökonometrischen Spezifikationen verworfen werden. 


\title{
How Does EU Cohesion Policy Work? Evaluating its Effects on Fiscal Outcome Variables
}

\author{
Tobias Hagen ${ }^{\star}$ and Philipp Mohl ${ }^{\star \star}$
}

September 12, 2009

\begin{abstract}
The impact of EU Cohesion Policy has mainly been evaluated with regard to its growth effects. We extend the perspective by investigating the impact of EU Cohesion Policy on public investments and budget deficits in order to learn more about the channels through which this policy field works. Using a dataset of $27 \mathrm{EU}$ countries for the time period 1982-2006, we find that EU Cohesion Policy payments do not cause public investments to increase significantly, which points to a crowding out of national investment. Moreover, the hypothesis that EU Cohesion Policy is used for the consolidation of public budgets cannot be completely rejected.
\end{abstract}

Keywords: EU Cohesion Policy, public investment, public deficits, panel data

JEL classification: $\mathrm{C} 23, \mathrm{H} 54, \mathrm{H} 62$

\footnotetext{
* University of Applied Labour Studies (HdBA), P.O. Box 250217, 68163 Mannheim, Germany, E-mail: tobiashagen@email.de

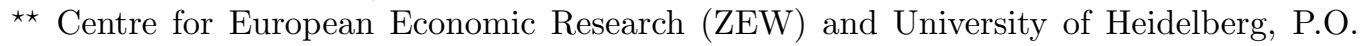
Box 103443, 68034 Mannheim, Germany, E-mail: philipp.mohl@gmail.com
} 


\section{Introduction}

The debate on the impact of the EU Cohesion Policy (CP) has intensified over the last decade. ${ }^{1}$ Many papers investigate if $\mathrm{CP}$ payments promote growth and convergence. Nevertheless, the results are not clear-cut: While some authors find evidence for a positive relation (Beugelsdijk and Eijffinger, 2005), others find no evidence (Dall'erba and Le Gallo, 2007) or even negative support for this (Eggert, von Ehrlich, Fenge and König, 2007). All in all, the discussion might be summarised by stating that the EU CP is only conditionally effective. Given the quality of the institutional setup (Ederveen, de Groot and Nahuis, 2006), decentralised governmental structures (Bähr, 2008) or depending on which Objective is analysed (Mohl and Hagen, 2008), the CP has a positive impact on growth (a literature survey can be found in Hagen and Mohl, 2010). ${ }^{2}$

The strong focus on growth neglects the fact that the EU Regional Policy might have an influence on other policy fields as well. There are at least two reasons why the impact on public investments might be of special interest. First of all, according to the principle of additionality the Member States have to co-finance EU funded projects but must not crowd out investment spending elsewhere (European Commission, 2007). Second, since a major part of the Cohesion Policy is spent on public investments (European Commission, 2004), virtually all empirical studies on the investigation of the growth effects assume that Cohesion Policy increases investments, leading to a higher steady-state capital per capita, which, in turn, increases the GDP

\footnotetext{
${ }^{1}$ The terms "EU Cohesion Policy" and "EU Regional Policy" can be used synonymously. Both mean the policy of the EU to co-finance national projects mostly carried out at the regional level by payments from the so-called "structural funds" (Ederveen, de Groot and Nahuis, 2006).

${ }^{2}$ Besides econometric studies evaluating Cohesion Policy directly, there is empirical evidence on the convergence of EU countries and regions (see Eckey and Türk (2006) for a survey). Most studies find a small convergence rate of all or some European regions. The effect of EU membership (again, without taking Cohesion Policy directly into account) is analysed by Cuaresma, Ritzberger-Grünwald and Silgoner (2008). They find EU membership to have a positive effect on long-term economic growth, which is relatively higher for poorer countries.
} 
growth rate. ${ }^{3}$ Hence, an essential condition for the effectiveness of EU transfers is the degree to which they affect overall public investments. However, the impact of Cohesion Policy payments on national public investments has not yet been evaluated. One paper empirically analyses the principle of additionality based on another approach. Using a cross-section of European regions, Ederveen, Gorter, de Mooij and Nahuis (2002) investigate the impact of being an Objective 1 region (that is, being eligible for the highest transfers) on national regional support. They find that, on average, one euro cohesion support crowds out 17 cents of national regional policy.

Furthermore, instead of increasing future-orientated spending, EU Cohesion Policy payments may (indirectly) be used to reduce public deficits. This is possible if EU funds crowd out national spending, which is most likely to occur in poorer countries. To the best of our knowledge, there has been no paper investigating the effects on public deficits.

Against this background, this paper analyses how the EU Cohesion Policy works by extending the current literature with regard to at least three aspects: First, we investigate the effects of EU Cohesion Policy on additional (fiscal) outcome variables, namely on public investment and public deficits. Second, we use a more comprehensive dataset comprising total EU Cohesion Policy payments. Third, we extend both the time period of investigation to the period 1982-2006 and the number of countries to an EU-27 sample. Our results show no significantly positive effects on national public investments and some weak evidence in favour of the hypothesis that the $\mathrm{CP}$ payments are used for public budget consolidation.

The paper is structured as follows. In section 2 we present the dataset used and discuss the main econometric approach. Section 3 presents the econometric specifications and the empirical results. Finally, section 4 concludes.

\footnotetext{
${ }^{3} \mathrm{CP}$ payments may influence long-run growth in two more ways (Esposti and Bussoletti, 2008; Bouvet, 2005). First, it may increase the initial level or the growth of the total factor productivity (TFP). Second, it may affect the labour market, that is, the initial workforce growth rate, which, in turn, has an impact on the steady-state output level.
} 


\section{Database and econometric approach}

We investigate our research question using an EU-27 annual country dataset consisting of total EU Cohesion Policy payments for the time period 19822006 (European Commission, 2008). This contains the different structural funds ${ }^{4}$ as well as the Cohesion Fund and the Instrument for Structural Policies for Pre-accession (ISPA) for the accession countries. A detailed description of the institutional setup can be found, among others, in European Commission (2007).

Figure 1 shows the historical development displaying the total nominal EU Cohesion Policy payments (vertical bars) and their shares relative to the EU-GNI (solid line) and to the public national spending (dotted line). It becomes clear that there is a long-term upward trend in payments when measured in absolute terms, which can be explained, inter alia, by the enlargement steps of the EU (Heinemann, Hagen, Mohl, Osterloh and Sellenthin, 2009). By contrast, payments measured in percent of EU-GNI and public national spending have almost consistently stagnated since 1993. Furthermore, Figure 1 shows that - on average - Cohesion payments do not seem to be very large compared to total public spending totalling approximately 0.65 percent in 2007.

Table 1 compares the expenditures for the EU Regional Policy with the national public investments and the primary surpluses. It becomes clear that Cohesion payments per GDP are quite important compared to total public investments in the so-called "old" (Spain, Greece, Ireland and Portugal) and the "new" (Eastern European Member States) cohesion countries. This indicates that it may indeed be hard for some countries to absorb the transfers and to co-finance European projects without cutting expenses elsewhere. Furthermore, it may be appealing for these countries in particular to reduce public deficits (increase primary surpluses) by displacing national funded projects by EU-funded projects.

Generally, we are keen on the estimation of "policy reaction" functions.

\footnotetext{
${ }^{4}$ These are the European Regional Development Fund (ERDF), the European Social Fund (ECP), the European Agricultural Guidance and Guarantee Fund (EAGGF) and the Financial Instrument for Fisheries Guidance (FIFG).
} 
Figure 1: Development of total EU Cohesion Policy payments

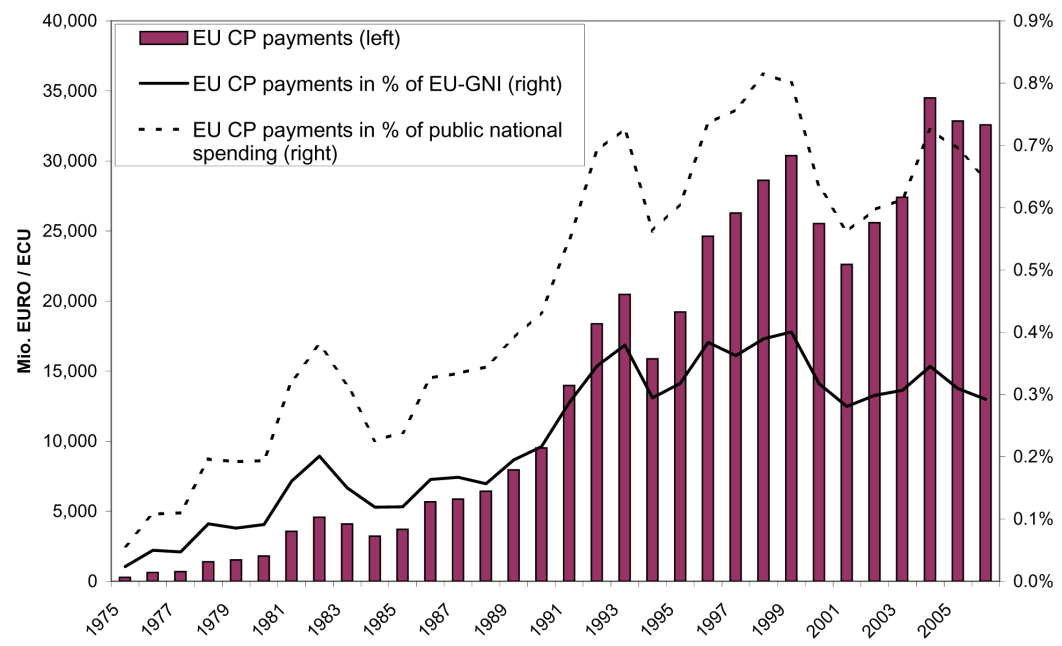

Source: European Commission (2008).

Since the level of CP commitments is decided for several years in advance within so called "financial frameworks", national governments can anticipate and react instantaneously to the forthcoming EU support. As a consequence, we include the contemporaneous $\mathrm{CP}$ variable, i.e. not lagged, in the regression model.

In order to render the empirical results as robust as possible, we use different samples and methodological approaches. Regarding the choice of the countries, we use two different samples. First, the regressions are estimated for the whole time period for which data is available ("all time periods"). Thus, countries are included even before their accession. For example, Austria and Finland are included even before 1994 and the Eastern European countries before 2004. Since the latter countries also received EU support before their accession, it is (potentially) possible to distinguish between the "EU effect" and the "CP payments effect". Second, we only include the time periods in which the countries are members of the EU ("only EU members"). By definition, the second strategy reduces the number of observations significantly.

Concerning the econometric approaches, we start the estimation using a simple fixed effects estimator. We report standard errors to be robust to 
serial and spatial correlation, following Driscoll and Kraay (1998). ${ }^{5}$ The error structure is then assumed to be heteroskedastic, autocorrelated and possibly correlated between the countries (panels). Since these standard errors have not been very common in applied work yet, we also report - as a kind of robustness check - the White-Huber robust standard errors (White, 1980).

Due to the structure of our dataset (depending on the specification, $N$ varies between 25 and 27, $T$ varies between 2 and 27 with an average of 17.1), simply applying a fixed effects estimator in a dynamic setup leads to the well-known Nickell bias (Nickell, 1981). One way to control for this is to use the first-differenced GMM estimator proposed by Arellano and Bond (1991). Since this estimator has been found to have a large finite sample bias and poor precisions when the time series are persistent, we use, whenever possible, the two-step system GMM (SYS-GMM) estimator by Blundell and Bond (1998). In addition, using the SYS-GMM estimator has the advantage of taking into account potential endogeneity of further explanatory variables, i.e., there may be unobserved variables simultaneously affecting the independent and the dependent variables. The consistency of the SYS-GMM estimator is based on large $N$, which is obviously not given in our application. However, recent Monte Carlo simulations show that, given the predetermined variables in $X$, the SYS-GMM estimator has a lower bias and higher efficiency than the first-differenced GMM or the fixed effects estimator (Soto, 2006). The small $N$ leads to a further problem: it is not possible to use the full set of instrumental variables since Windmeijer (2005) or Roodman (2009b) show that using too many instruments leads to biased results. For this reason, only recent values up to three lags are used. For a small panel size, Soto (2006) shows that not using all potentially available instruments does not decrease the reliability of the SYS-GMM estimator.

Furthermore, in order to mitigate the problem of too many instruments in the case of the SYS-GMM specification, we transform all our variables into deviations from time means, which is equivalent to the inclusion of time dummies. This decreases the total number of instruments and increases the degrees of freedom (Bond, Hoeffler and Temple, 2001). Instead of using all possible instruments for each available time period, we "collapse" the matrix

\footnotetext{
${ }^{5}$ The Stata command $x t s c c$ implemented by Hoechle (2007) is applied.
} 
of instruments and only use the lags up to $t-2$ which leads to a smaller set of instruments. In addition, regarding the two-step SYS-GMM estimations, the standard errors are corrected following Windmeijer (2005). ${ }^{6}$

Another estimation strategy to deal with the Nickell bias is to apply the bias-corrected least square dummy variable (LSDVc) estimator proposed by Kiviet (1995) and extended by Bruno (2005a,b) to unbalanced panel data, ${ }^{7}$ which turns out to have better properties in the case of small $N$ (Bruno, 2005a; Judson and Owen, 1999). An obvious drawback of this estimator is the assumption of strict exogeneity of all explanatory variables (except for the lagged dependent variable). The standard errors of the LSDVc are bootstrapped (500 replications).

Due to our long time series, which comprises more than 20 years, our results might be affected by the problem of non-stationarity. Hence, we run Fisher type unit root tests for panel data following Maddala and Wu (1999). ${ }^{8}$ The results reject the null hypothesis that the main variables of interest (CP payments per GDP, public investment per GDP and primary surplus per GDP) are non-stationary for all countries.

\section{Empirical results}

\subsection{Effects on national public investments}

We start our empirical analysis by investigating whether and to which extent EU Cohesion Policy payments lead to higher national public investments. Put differently, we evaluate if Cohesion payments are "additional", or if they only lead to a displacement of national public investments. In fact, the Member States' obligation to co-finance projects by the principle of ad-

\footnotetext{
${ }^{6}$ The Stata command xtabond2 implemented by Roodman (2009a) is applied.

${ }^{7}$ The Stata command $x t l s d v c$ implemented by Bruno (2005a) is applied. The SYS-GMM estimator (Blundell and Bond, 1998) is used to initialize the bias correction. The accuracy of the approximation is up to $O\left(1 / N T^{2}\right)$.

${ }^{8}$ The Stata command $x$ fisher implemented by Scott Merryman is used. Results are available upon request.
} 
ditionality $^{9}$ should ensure that an increase in European payments promotes domestically-financed investments, thus causing total national public investments to increase as well. Generally, the principle of additionality implies that EU funds can only be paid in addition to the Member States' investments and not instead of it. In practice, however, additionality is hard to control and, more importantly, it has not been sanctioned in the past. This leads to the suspicion that Cohesion payments displace at least some part of the domestic public investments.

The econometric analysis of national public investments $\left(\right.$ pinv $\left._{i t}\right)$ is based on a similar specification to the one by Mehrotra and Välilä (2006) for European countries. An obvious problem may arise from the fact that we do not observe all possibly relevant variables that determine the scale and timing of national public investments. For example, not only macroeconomic variables are relevant, but also unobserved variables such as government programmes and country specific peculiarities (e.g., natural disasters etc.). Since these variables may simultaneously affect $\mathrm{CP}$ payments, their omission may lead to biased estimates. In order to deal with this problem, we follow, inter alia, Nunziata (2005) by using a very flexible specification, where not only fixed country effects $\left(\mu_{i}\right)$ and fixed (annual) time effects $\left(\lambda_{t}\right)$ are included, but also country-specific linear time trends $\left(t_{i}\right)$. In this manner, we intend to control for unobserved fixed and time varying heterogeneity that affects all outcome variables apart from CP payments. Note that country-specific time trends are not possible for the SYS-GMM estimator since this would inflate the IV matrix. We estimate following model:

$$
\begin{aligned}
\text { pinv }_{i t}= & \beta_{0}+\alpha \text { pinv }_{i t-1}+\beta_{1} d_{i t-1}+\beta_{2} g_{i t-1}+\beta_{3} \text { gdppc }_{i t-1}+\beta_{4} E_{i t} \\
& +\beta_{5} \text { cp }_{i t}+\beta_{6} \text { contrib }_{i t}+\beta_{7} l_{i t}+\beta_{8} \text { open }_{i t-1}+\beta_{9} \text { elect }_{i t} \\
& +\beta_{10} \text { left }_{i t}+\gamma_{i} t_{i}+\mu_{i}+\lambda_{t}+\varepsilon_{i t}
\end{aligned}
$$

The motivation for this specification is as follows. Since public debt $\left(d_{i t-1}\right)$ indicates the need for consolidating public finance, it should have a

\footnotetext{
${ }^{9}$ According to the principle of additionality, the EU transfers complement the contributions of the Member States rather than reducing them. Disregarding special exceptions, the Member States must maintain public spending at a level no less than that reached in the preceding period (European Commission, 2007).
} 
negative impact on public investments. The growth rate of real GDP per capita $\left(g_{i t-1}\right)$ serves as a business cycle indicator. ${ }^{10}$ The level of real GDP per capita $\left(g d p p c_{i t-1}\right)$ controls for the hypothesis that demand for public investments may depend on the income level. Moreover, real GDP per capita is the most important allocation criteria for CP. The long-term interest rate $\left(l i_{i t}\right)$ is a proxy for the opportunity costs of public investments, while open ${ }_{i t-1}$ (export plus imports per GDP) controls for the possibility that the demand for public investments may depend on the openness of the economy. In the case of the sample "all time periods" the dummy variable $E U_{i t}$ controls for possible membership effects.

Moreover, there is evidence that political economic variables might have an impact on the dependent variable (Persson and Tabellini, 2000; Tabellini and Alesina, 1990). Thus, we include two further control variables as a proxy for political effects: elect ${ }_{i t-1}$ measures the percentage share of pre-election months in each election year and $l_{e} t_{i t}$ gives the cabinet composition (Social Democratic and other left parties in percent of total cabinet posts).

Moreover, contrib $b_{i t}$ are total contributions from the national Member States to the EU (total revenues of the EU from so-called own resources) in percentage of GDP. This variable controls for the fact that payments to the EU may limit the fiscal scope of national governments. Furthermore, the national claims for payments from the EU may simply be determined by the Member States' considerations with regard to their net contribution to the EU budget (the difference between what the countries pay into the EU budget and what they receive from EU policies). ${ }^{11} c p_{i t}$ measures total $\mathrm{CP}$ payments to country $i$ in percent of GDP. Eventually, the lagged dependent variable $\left(\right.$ pinv $\left._{i t-1}\right)$ controls for the path dependency of public investment. The description and the summary statistics of the variables used can be found in Table 2 and Table 3 in the Appendix.

The estimation results can be found in Table 4. As mentioned above, we

\footnotetext{
${ }^{10}$ On the one hand, it has a positive effect on public investments if the amount of public investments depends on tax revenues. On the other hand, the government may conduct an anti-cyclical policy, which leads to a negative effect.

${ }^{11}{ }^{c o n t r i b} b_{i t}$ and $c p_{i t}$ are weakly positively correlated with a correlation coefficient of 0.14 (p-value 0.008) in our sample.
} 
differentiate between two samples ("all time periods" and "only EU members"). Furthermore, various estimators are applied. Columns (1) and (5) contain static fixed effects estimators restricting to zero, where the displayed standard errors are either White-Huber robust or specified following Driscoll and Kraay (1998). Column (2) shows the results of fixed effects estimators applied to a dynamic specification. Since the latter strategy leads to the Nickell bias, ${ }^{12}$ we also present the results of the bias-corrected dummy variable estimator (LSDVc) in columns (3) and (6). Finally, in columns (4) and (7) the results of the SYS-GMM specifications are shown, which allow for endogeneity of $d_{i t-1}, g d p p c_{i t-1}$, contrib $b_{i t}$, and $c p_{i t}$ (besides $p i n v_{i t-1}$ ). As mentioned above, the SYS-GMM specification should be interpreted with caution, since $N$ may be too small.

Table 4 shows that many of the estimated coefficients of the covariates have the expected signs. An increasing stock of public debt $\left(d_{i t-1}\right)$ (with the exception of the SYS-GMM specifications) leads to less public investments, which corresponds to the findings of Mehrotra and Välilä (2006). By contrast, the effect of a rise in the opportunity costs (real interest rates $l i_{i t}$ ) is less clear, suggesting that cost considerations seem to play only a minor role in government investment decisions. While GDP growth $\left(g_{i t-1}\right)$ affects public investments positively, indicating a pro-cyclical behaviour, the GDP level $\left(g d p p c_{i t-1}\right)$ has (with one exception) a negative effect. ${ }^{13}$ Moreover, we find significant robust results in all specifications for the lagged dependent variable and the public debt. The political variables also have the expected sign and the coefficient of left $t_{i t}$ is statistically significant, whereas election years do not have a significant impact. Contributions to the EU (contrib ${ }_{i t}$ ) do not seem to reduce public investments.

Generally, the results do not change significantly when standard errors are specified according to Driscoll and Kraay (1998). The disregard of the Nickell bias in column (2) leads, as expected, to an underestimation of the

\footnotetext{
${ }^{12}$ Since $\mathrm{T}$ varies between 3 and 31 with an average of 16.3 , the bias may still be substantial (Judson and Owen, 1999).

${ }^{13}$ This result is in contrast to the one by Mehrotra and Välilä (2006). They interpret their result of a positive effect of the output level as evidence in favour of the hypothesis that public investments have characteristics of a luxury good.
} 
lagged dependent variable. Moreover, the decrease of the sample size to the case of EU members only does not lead to different conclusions. Instead, the signs and the significance levels remain stable regardless of the choice of the specification.

The focus of our investigation lies on the Cohesion Policy variable. As Table 4 shows, all coefficients of $c p_{i t}$ are far from being significant. This is true for all econometric techniques and both samples. The estimated longterm effects of $\widehat{c p}_{i t}\left(\widehat{\beta}_{5} /(1-\widehat{\alpha})\right)$ are not shown since they are far from being significantly different from zero.

In order to validate our results we run further sensitivity analyses. First, one may argue that using country-specific time trends may lead to an "overspecification" in the sense of multicollinearity with other explanatory variables or the possibility that the variance of the dependent variable is "absorbed" to a large extent. For this reason, Table 5 in the Appendix shows the results when country-specific time trends are omitted. Note that the SYSGMM models in the paper already omit the country-specific time trends so that these sensitivity analyses do not include SYS-GMM models. It can be seen that the basic results do not change.

Second, we exclude the political variables $\left(\right.$ elect $_{i t}$, left $_{i t}$ ) as well as the contributions to EU (contrib $b_{i t}$ ) in order to receive a more parsimonious estimation. The regression output displayed in Table 6 shows that this leaves our main finding untouched: $c p_{i t}$ is still not significant.

Third, the governments might not have complete knowledge on the future CP payments, e.g. due to problems in absorbing total structural funds. Thus, we re-run the regressions using lagged $\mathrm{CP}$ variables $\left(c p_{i t-1}\right)$, which does not change our key message (Table 7).

Fourth, in the SYS-GMM specifications we assumed that apart from the lagged dependent variable, only Cohesion Policy and the contributions to the EU are endogenous, which allows for a very parsimonious use of instruments. Nevertheless, the $c p_{i t-1}$ variable is still far from being significant. ${ }^{14}$

Finally, some empirical applications question the superiority of the SYSGMM estimator mainly because the additional instruments might not be valid (Lucchetti, Papi and Zazzaro, 2001). As a consequence, we use the first-

\footnotetext{
${ }^{14}$ These results are not shown, but are available upon request.
} 
differenced GMM estimator as an alternative estimator and again instrument $d_{i t-1}, g d p p c_{i t-1}$, contrib $_{i t}$ and $c p_{i t-1}$ (besides pinv $v_{i t-1}$ ), using a lag-limit and the collapse option. Again, the effect of $c p_{i t}$ is zero (Table 8).

Summarising the results, no statistically significant positive effect of EU Cohesion Policy on national public investments can be detected, irrespective of which sample and which method is used. As a consequence, it cannot be ruled out that CP simply serves as a substitute for domestically-financed investment projects.

\subsection{Effects on national primary budget balances}

After having found that, on average, EU Cohesion Policy does not have any measurable positive impact on public investments, we now analyse how Member States might make use of their increased financial scope. One possibility is that the resources are used for reducing public deficits.

In order to analyse this hypothesis, we use the primary budget balances as the dependent variable. The primary budget balance is the difference between non-interest spending and total revenues. It can be affected by the government much more rapidly than the total budget surplus, since it excludes interest payments, which are exogenous for the government in the short-run. Furthermore, by using this variable, a clear-cut theoretical foundation is available (Bohn, 1998).

One would expect the $\mathrm{CP}$ payments, ceteris paribus, to have a negative impact on primary surplus if countries co-finance projects by additional means without altering the structure of public spending (government consumption versus investment). By contrast, if national spending were cut, CP payments would have a positive impact. The mean primary balances as percent of GDP of the EU countries can be found in Table 1.

A framework for explaining public debt policy is formulated by Bohn (1998). This approach explains the primary budget balance as percent of GDP $\left(b_{i t}\right)$ by the public debt stock (as percent of GDP) at the beginning of the period $\left(d_{i t-1}\right)$ as well as further variables in a time series context. ${ }^{15}$

\footnotetext{
${ }^{15}$ If the estimated coefficient of $d_{i t-1}$ is positive, i.e., there is a positive response of the primary surplus to the debt-GDP ratio. As shown by Bohn (1998), this implies that
} 
In the following, this concept is applied to our panel of countries and the research goal at hand:

$$
\begin{aligned}
\text { bal }_{i t}= & \beta_{0}+\alpha \text { bal }_{i t-1}+\beta_{1} d_{i t-1}+\beta_{2} g_{i t-1}+\beta_{3} \text { gdppc }_{i t-1}+\beta_{4} E U_{i t} \\
& +\beta_{5} \text { cp }_{i t}+\beta_{6} \text { contrib }_{i t}+\beta_{7} \text { li }_{i t}+\beta_{8} \text { open }_{i t-1}+\beta_{9} \text { elect }_{i t} \\
& +\beta_{10} \text { left }_{i t}+\gamma_{i} t_{i}+\mu_{i}+\lambda_{t}+\varepsilon_{i t}
\end{aligned}
$$

In fact, this specification is rather similar to the one applied to the public investment decision above. Again, it is controlled for country-specific linear time trends $\left(t_{i}\right)$. A description of the variables used can be found in Table 4 in the Appendix. The long-term interest rate $\left(i t_{i t}\right)$ is a proxy for the opportunity

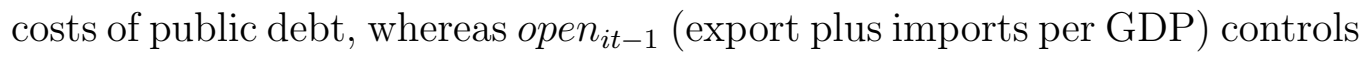
for the possibility that the governments of more open economies choose a more restrictive fiscal policy. Again, it is controlled for the income level and GDP growth $\left(g d p p c_{i t-1}, g_{i t-1}\right)$. Higher contributions to the EU (contrib $\left.b_{i t}\right)$ may imply higher budget deficits. With regard to political considerations, the variables elect ${ }_{i t}$ and $l e f t_{i t}$ are included once again.

The estimation results are shown in Table 9. Again, different samples and various econometric techniques are applied. Columns (1) and (5) show the results of static fixed effects models assuming strict exogeneity of all regressors. Furthermore, ignoring the "Nickell bias", column (2) includes the results of a dynamic fixed effects specification. Columns (3) and (6) display the results of the LSDVc (see last subsection). In columns (4) and (7), SYSGMM models additionally allow for endogeneity of $d_{i t-1}, g_{i t-1}, g d p p c_{i t-1}$, contrib $b_{i t}$ and $c p_{i t}$, whilst omitting country-specific time trends $\left(t_{i}\right)$.

First we take a look at the control variables. The coefficient of $d_{i t-1}$ has the expected positive sign which is not statistically significant from zero in the case of the SYS-GMM only. Hence, on average, high public debt brings (or forces) governments to generate higher primary surpluses. In some specifications, the same holds true for the long-term interest rate $\left(l i_{i t}\right)$. Economic growth $\left(g_{i t-1}\right)$ helps to increase the primary surplus. Ultimately, election years $\left(\right.$ elect $\left._{i t}\right)$ are associated with reduced budget surpluses, which is well

the fiscal policy is sustainable in that it satisfies an intertemporal budget constraint. However, since the estimated coefficient here is an (unweighted) average of $N$ different countries, it is not relevant to this issue. 
documented in the literature (see, for example Shi and Svensson, 2003, for an overview). The effect of the contributions to the $\mathrm{EU}\left(E U_{i t}\right)$ is not clearcut.

With regard to the estimated coefficients of $c p_{i t}$, it can be seen that $\mathrm{CP}$ payments have a significantly positive impact on primary surpluses in the case of fixed effects specifications. However, the significances vanish using the LSDVc and the SYS-GMM. Nevertheless, the hypothesis that countries use the CP payments to indirectly reduce their deficits cannot be rejected, since we would otherwise have expected to find a negative effect.

Again we run several robustness regressions (without county-specific time trends, without contribution payments to the EU and political variables, lagged CP instead of contemporaneous CP, one-step FD-GMM instead of two-step SYS-GMM). The results can be found in Appendix (Tables $10-$ 13). Again, the results hardly change: No significantly negative impact of $\mathrm{CP}$ payments can be detected.

\section{Conclusion}

The previous studies analysing the impact of EU Cohesion Policy have mainly focused on the investigation of its economic growth effects and have mainly led to inconclusive results. In this paper we broaden this perspective in attempting to analyse through which fiscal channels the EU Cohesion Policy works or does not work. We investigate the impact of Cohesion Policy payments on public investment and on primary budget balances by estimating policy reaction functions. In doing so, we use more appropriate data within a greater time span, applying advanced panel data methods.

Our results show that EU Cohesion Policy payments do not seem to increase public investments in the EU countries, indicating a crowding out process of national spending. Furthermore, the hypothesis that EU funds are used for the consolidation of public budgets cannot be rejected in all econometric specifications.

Our findings have at least two implications. First, they might explain the mixed results of previous growth studies on Cohesion Policy, which are almost exclusively based on the assumption that EU Regional Policy increases 
investments, which - at least at the national level - seems not to be the case. Second, the policy conclusions are that the principle of additionality (stating that domestically funded projects must not be displaced by EU projects) should be monitored and sanctioned more carefully in order to ensure that Cohesion Policy payments lead to higher public investments.

\section{Acknowledgements}

We thank Ron Davies and Diana Sonntag as well as the participants of the European Public Choice conference in Athens (2009) and the International Institute of Public Finance in Cape Town (2009) for their helpful and valuable comments. 


\section{Appendix}

Table 1: EU Cohesion Policy payments, national public investments and primary budgets as percent of GDP

\begin{tabular}{|c|c|c|c|c|}
\hline & $\begin{array}{c}\text { EU CP } \\
\text { payments } \\
(\text { as \% of GDP) }\end{array}$ & $\begin{array}{c}\text { Public } \\
\text { investments } \\
\text { (as \% of GDP) }\end{array}$ & $\begin{array}{c}\text { Primary } \\
\text { balance } \\
\text { (as \% of GDP) }\end{array}$ & $\begin{array}{c}\text { Time period } \\
\text { from } . . . \\
\text { until } 2007\end{array}$ \\
\hline & (1) & $(2)$ & (3) & $(4)$ \\
\hline Austria & 0.13 & 1.59 & 1.17 & 1995 \\
\hline Belgium & 0.10 & 2.12 & 3.38 & 1982 \\
\hline Bulgaria & 1.00 & 3.62 & 3.40 & 2000 \\
\hline Czech Republic & 0.07 & 3.26 & 0.76 & 2000 \\
\hline Cyprus & 0.34 & 4.39 & -3.10 & 2002 \\
\hline Denmark & 0.08 & 1.84 & 5.03 & 1982 \\
\hline Estonia & 0.93 & 4.13 & 1.61 & 2000 \\
\hline Finland & 0.21 & 2.71 & 4.60 & 1995 \\
\hline France & 0.13 & 3.21 & -0.33 & 1982 \\
\hline Germany & 0.12 & 2.16 & 0.78 & 1982 \\
\hline Greece & 1.53 & 3.00 & 0.57 & 1982 \\
\hline Hungary & 0.54 & 3.85 & -2.19 & 2000 \\
\hline Ireland & 1.34 & 3.12 & 3.25 & 1982 \\
\hline Italy & 0.24 & 2.69 & 0.96 & 1982 \\
\hline Latvia & 1.69 & 2.87 & -0.59 & 2000 \\
\hline Lithuania & 1.09 & 3.34 & -0.58 & 2000 \\
\hline Luxembourg & 0.09 & 4.17 & 2.58 & 1990 \\
\hline Malta & 0.25 & 4.31 & -1.00 & 2002 \\
\hline Netherlands & 0.06 & 3.28 & 2.00 & 1982 \\
\hline Poland & 0.58 & 3.41 & -1.55 & 2000 \\
\hline Portugal & 2.19 & 3.45 & 0.31 & 1986 \\
\hline Romania & 0.59 & 3.52 & -0.35 & 2000 \\
\hline Slovak Republic & 0.59 & 2.53 & -2.46 & 2000 \\
\hline Slovenia & 0.27 & 3.37 & -0.39 & 2000 \\
\hline Spain & 0.84 & 3.76 & 1.85 & 1986 \\
\hline Sweden & 0.10 & 3.13 & 3.67 & 1995 \\
\hline UK & 0.15 & 1.83 & 0.83 & 1982 \\
\hline
\end{tabular}

Notes: Own calculations based on European Commission (2008). We restrict the statistics to the years in which positive CP payments are observable; the earliest year is 1982 . 
Table 2: Definition of the variables

\begin{tabular}{|c|c|c|}
\hline Variable & Definition & Source \\
\hline $\operatorname{pinv}$ & $\begin{array}{l}\text { Gross fixed capital formation of the general } \\
\text { government (as \% of GDP) }\end{array}$ & AMECO \\
\hline bal & $\begin{array}{l}\text { General government primary balance (as } \% \text { of } \\
\text { GDP) }\end{array}$ & OECD \\
\hline$d$ & $\begin{array}{l}\text { General government gross financial liability } \\
\text { (as \% of GDP) }\end{array}$ & WEO \\
\hline$l i$ & Real long-term interest rate in percent & AMECO \\
\hline open & $\begin{array}{l}\text { Openness of the economy (imports plus exports } \\
\text { as \% of GDP) }\end{array}$ & WEO \\
\hline$g$ & Growth of real GDP per capita & WDI \\
\hline$g d p p c / 1,000$ & Level of real GDP per capita in Dollar in PPP & WDI \\
\hline elect & Share of pre-election months in each year & Armingeon et al. (2008) \\
\hline left & $\begin{array}{l}\text { Cabinet composition: Social-Democratic and } \\
\text { other left parties as } \% \text { of total cabinet posts, } \\
\text { weighted by days }\end{array}$ & Armingeon et al. (2008) \\
\hline$E U$ & Dummy for membership in the EU & \\
\hline$c p$ & $\begin{array}{l}\text { Total EU Cohesion Policy payments (as \% of } \\
\text { nominal GDP) }\end{array}$ & $\begin{array}{l}\text { European Commission (2008) } \\
\text { and WDI }\end{array}$ \\
\hline contrib & $\begin{array}{l}\text { National payments to the EU (revenues of the EU } \\
\text { from so-called own resources) (as \% of } \\
\text { nominal GDP) }\end{array}$ & $\begin{array}{l}\text { European Commission (2008) } \\
\text { and WDI }\end{array}$ \\
\hline
\end{tabular}

Notes: WDI $=$ World Development Indicators (Worldbank); WEO = World Economic Outlook (IMF); AMECO = Annual Macro-Economic Database of the European Commission, DG ECFIN; OECD = OECD Economic Outlook Database; Armingeon et al. (2008) = Armingeon, Gerber, Leimgruber and Beyeler (2008).

Table 3: Descriptive statistics for the estimation sample

\begin{tabular}{lrrrrr}
\hline Variable & $\begin{array}{r}\text { Number } \\
\text { of obs. }\end{array}$ & Mean & $\begin{array}{c}\text { Std. } \\
\text { dev. }\end{array}$ & Min. & Max. \\
\hline pinv & 439 & 2.99 & 0.88 & 0.67 & 5.13 \\
bal & 406 & 1.34 & 2.96 & -8.17 & 11.62 \\
$d$ & 439 & 56.54 & 28.55 & 4.06 & 134.16 \\
li & 439 & 7.82 & 3.84 & 3.30 & 27.53 \\
open & 439 & 91.34 & 52.24 & 35.89 & 347.18 \\
g & 439 & 2.60 & 2.50 & -6.75 & 12.31 \\
gdppc/1,000 & 439 & 23.70 & 10.86 & 0.43 & 112.81 \\
elect & 439 & 0.15 & 0.28 & 0.00 & 1.00 \\
left & 439 & 39.87 & 37.00 & 0.00 & 100.00 \\
EU & 439 & 0.79 & 0.41 & 0.00 & 1.00 \\
contrib & 439 & 7.36 & 4.19 & 0.00 & 15.12 \\
cp & 439 & 0.47 & 0.69 & 0.00 & 3.50 \\
\hline
\end{tabular}


Table 4: Determinants of national public investments

\begin{tabular}{|c|c|c|c|c|c|c|c|}
\hline & \multicolumn{4}{|c|}{ All time periods } & \multicolumn{3}{|c|}{ Only EU members } \\
\hline & $\begin{array}{l}\text { FE } \\
\text { stat. }\end{array}$ & $\begin{array}{l}\text { FE } \\
\text { dyn. }\end{array}$ & LSDVc & $\begin{array}{l}\text { SYS- } \\
\text { GMM }\end{array}$ & $\begin{array}{l}\text { FE } \\
\text { stat. }\end{array}$ & LSDVc & $\begin{array}{l}\text { SYS- } \\
\text { GMM }\end{array}$ \\
\hline & $(1)$ & $(2)$ & (3) & (4) & $(5)$ & (6) & (7) \\
\hline $\operatorname{pinv}_{i t-1}$ & & $\begin{array}{l}0.461 \\
(7.11) \\
{[4.86]} \\
\end{array}$ & $\begin{array}{c}0.622 \\
(13.86)\end{array}$ & $\begin{array}{l}0.639 \\
(4.49)\end{array}$ & & $\begin{array}{c}0.639 \\
(10.54)\end{array}$ & $\begin{array}{c}0.63 \\
(4.06)\end{array}$ \\
\hline$d_{i t-1}$ & $\begin{array}{c}-0.038 \\
(-10.24) \\
{[-11.77]}\end{array}$ & $\begin{array}{l}-0.02 \\
(-5.95) \\
{[-5.86]}\end{array}$ & $\begin{array}{l}-0.015 \\
(-4.67)\end{array}$ & $\begin{array}{l}-0.012 \\
(-2.25)\end{array}$ & $\begin{array}{l}-0.041 \\
(-10.90) \\
{[-11.18]}\end{array}$ & $\begin{array}{l}-0.017 \\
(-3.90)\end{array}$ & $\begin{array}{l}-0.016 \\
(-1.97)\end{array}$ \\
\hline$l i_{i t}$ & $\begin{array}{l}-0.02 \\
(-1.42) \\
{[-0.98]} \\
\end{array}$ & $\begin{array}{l}-0.019 \\
(-1.63) \\
{[-1.34]} \\
\end{array}$ & $\begin{array}{l}-0.021 \\
(-0.97)\end{array}$ & $\begin{array}{c}0.025 \\
(-1.28)\end{array}$ & $\begin{array}{l}-0.01 \\
(-0.57) \\
{[-0.38]} \\
\end{array}$ & $\begin{array}{l}-0.011 \\
(-0.37)\end{array}$ & $\begin{array}{c}0.029 \\
(-1.46)\end{array}$ \\
\hline open $_{i t-1}$ & $\begin{array}{l}0.005 \\
(1.19) \\
{[1.18]} \\
\end{array}$ & $\begin{array}{l}0.002 \\
(0.57) \\
{[0.76]} \\
\end{array}$ & $\begin{array}{l}0.002 \\
(0.64)\end{array}$ & $\begin{array}{l}0.002 \\
(0.75)\end{array}$ & $\begin{array}{l}0.004 \\
(0.89) \\
{[0.83]} \\
\end{array}$ & $\begin{array}{l}0.001 \\
(0.25)\end{array}$ & $\begin{array}{l}0.001 \\
(0.34)\end{array}$ \\
\hline$g_{i t-1}$ & $\begin{array}{l}0.017 \\
(1.40) \\
{[1.78]}\end{array}$ & $\begin{array}{c}0.02 \\
(1.76) \\
{[2.11]}\end{array}$ & $\begin{array}{l}0.021 \\
(1.52)\end{array}$ & $\begin{array}{l}0.004 \\
(0.31)\end{array}$ & $\begin{array}{l}0.002 \\
(0.14) \\
{[0.15]}\end{array}$ & $\begin{array}{l}0.012 \\
(0.53)\end{array}$ & $\begin{array}{l}0.011 \\
(0.58)\end{array}$ \\
\hline$g d p p c_{i t-1} / 1,000$ & $\begin{array}{l}-0.019 \\
(-2.64) \\
{[-2.62]} \\
\end{array}$ & $\begin{array}{l}-0.011 \\
(-1.78) \\
{[-1.90]} \\
\end{array}$ & $\begin{array}{l}-0.009 \\
(-0.50)\end{array}$ & $\begin{array}{l}0.005 \\
(0.53)\end{array}$ & $\begin{array}{l}-0.016 \\
(-1.97)\end{array}$ & $\begin{array}{l}-0.004 \\
(-0.18)\end{array}$ & $\begin{array}{l}-0.003 \\
(-0.58)\end{array}$ \\
\hline$c p_{i t}$ & $\begin{array}{l}-0.133 \\
(-1.49) \\
{[-1.60]}\end{array}$ & $\begin{array}{l}-0.035 \\
(-0.52) \\
{[-0.68]}\end{array}$ & $\begin{array}{l}-0.029 \\
(-0.38)\end{array}$ & $\begin{array}{l}0.026 \\
(0.14)\end{array}$ & $\begin{array}{l}-0.063 \\
(-0.63)\end{array}$ & $\begin{array}{l}0.032 \\
(0.34)\end{array}$ & $\begin{array}{l}-0.003 \\
(-0.01)\end{array}$ \\
\hline contrib $_{i t}$ & $\begin{array}{l}0.013 \\
(0.69) \\
{[0.43]}\end{array}$ & $\begin{array}{c}0.014 \\
(0.87) \\
{[0.66]}\end{array}$ & $\begin{array}{l}0.017 \\
(0.86)\end{array}$ & $\begin{array}{l}0.005 \\
(1.02)\end{array}$ & $\begin{array}{l}0.042 \\
(1.98)\end{array}$ & $\begin{array}{l}0.034 \\
(1.60)\end{array}$ & $\begin{array}{l}0.071 \\
(1.61)\end{array}$ \\
\hline elect $_{i t}$ & $\begin{array}{l}0.029 \\
(0.45) \\
{[0.50]} \\
\end{array}$ & $\begin{array}{l}0.062 \\
(1.24) \\
{[1.35]} \\
\end{array}$ & $\begin{array}{l}0.073 \\
(1.27)\end{array}$ & $\begin{array}{l}0.069 \\
(1.33)\end{array}$ & $\begin{array}{l}-0.011 \\
(-0.16)\end{array}$ & $\begin{array}{l}0.027 \\
(0.34)\end{array}$ & $\begin{array}{l}0.032 \\
(0.74)\end{array}$ \\
\hline left $t_{i t}$ & $\begin{array}{l}0.002 \\
(3.05) \\
{[3.04]}\end{array}$ & $\begin{array}{l}0.001 \\
(2.35) \\
{[2.48]}\end{array}$ & $\begin{array}{l}0.001 \\
(1.27)\end{array}$ & $\begin{array}{l}0.002 \\
(1.23)\end{array}$ & $\begin{array}{l}0.003 \\
(3.48)\end{array}$ & $\begin{array}{l}0.001 \\
(1.78)\end{array}$ & $\begin{array}{l}0.002 \\
(1.25)\end{array}$ \\
\hline$E U_{i t}$ & $\begin{array}{c}0.234 \\
(-0.69) \\
{[0.90]} \\
\end{array}$ & $\begin{array}{l}-0.069 \\
(-0.37) \\
{[-0.43]} \\
\end{array}$ & $\begin{array}{l}-0.135 \\
(-0.68)\end{array}$ & $\begin{array}{l}-0.313 \\
(-0.60)\end{array}$ & & & \\
\hline $\begin{array}{l}\text { Time dummies } \\
\text { (p-value) } \\
\text { Time trend } \\
\text { (p-value) }\end{array}$ & $\begin{array}{c}\text { yes } \\
0.000 \\
\text { specific } \\
0.000\end{array}$ & $\begin{array}{c}\text { yes } \\
0.000 \\
\text { specific } \\
0.000\end{array}$ & $\begin{array}{c}\text { yes } \\
0.000 \\
\text { specific } \\
0.000\end{array}$ & $\begin{array}{c}\text { yes } \\
\text { (time demean) } \\
\text { no }\end{array}$ & $\begin{array}{c}\text { yes } \\
0.000 \\
\text { specific } \\
0.000\end{array}$ & $\begin{array}{c}\text { yes } \\
0.000 \\
\text { specific } \\
0.000\end{array}$ & $\begin{array}{c}\text { yes } \\
\text { (time demean) } \\
\text { no }\end{array}$ \\
\hline No. instrum. & & & & 40 & & & 39 \\
\hline Hansen (p-value) & & & & 0.988 & & & 0.946 \\
\hline $\begin{array}{l}\mathrm{AR}(2) \text { test (p-value) } \\
\mathrm{R} 2 \text { (within) }\end{array}$ & & & & 0.296 & & & 0.43 \\
\hline $\begin{array}{l}\text { R2 (within) } \\
\text { No. of countries }\end{array}$ & $\begin{array}{c}0.692 \\
27\end{array}$ & $\begin{array}{c}0.761 \\
27\end{array}$ & 27 & 27 & $\begin{array}{c}0.678 \\
25\end{array}$ & 25 & 25 \\
\hline No. of obs. & 439 & 436 & 436 & 408 & 347 & 347 & 320 \\
\hline
\end{tabular}

Notes: t-values in parentheses if not stated otherwise: FE: (White-Huber robust s.e.) / [Driscoll-Kraay s.e.]; LSDVc: 500 bootstrap replications. 
Table 5: Determinants of national public investments (without countryspecific time trend)

\begin{tabular}{|c|c|c|c|c|c|}
\hline & \multicolumn{3}{|c|}{ All time periods } & \multicolumn{2}{|c|}{ Only EU members } \\
\hline & $\begin{array}{c}\text { FE } \\
\text { stat. }\end{array}$ & $\begin{array}{l}\text { FE } \\
\text { dyn. }\end{array}$ & LSDVc & $\begin{array}{c}\text { FE } \\
\text { stat. }\end{array}$ & LSDVc \\
\hline & (1) & (2) & (3) & (4) & (5) \\
\hline $\operatorname{pinv}_{i t-1}$ & & $\begin{array}{c}0.685 \\
(16.4) \\
{[14.38]}\end{array}$ & $\begin{array}{c}0.782 \\
(21.27)\end{array}$ & & $\begin{array}{c}0.757 \\
(16.16)\end{array}$ \\
\hline$d_{i t-1}$ & $\begin{array}{l}-0.017 \\
(-6.88) \\
{[-5.63]} \\
\end{array}$ & $\begin{array}{l}-0.008 \\
(-4.24) \\
{[-4.92]} \\
\end{array}$ & $\begin{array}{l}-0.007 \\
(-3.55)\end{array}$ & $\begin{array}{l}-0.018 \\
(-7.17) \\
{[-5.49]}\end{array}$ & $\begin{array}{l}-0.008 \\
(-3.40)\end{array}$ \\
\hline$l i_{i t}$ & $\begin{array}{l}-0.046 \\
(-3.62) \\
{[-3.20]} \\
\end{array}$ & $\begin{array}{l}-0.019 \\
(-2.20) \\
{[-2.45]} \\
\end{array}$ & $\begin{array}{l}-0.018 \\
(-1.39)\end{array}$ & $\begin{array}{l}-0.014 \\
(-0.88) \\
{[-0.55]} \\
\end{array}$ & $\begin{array}{l}-0.005 \\
(-0.30)\end{array}$ \\
\hline open $_{i t-1}$ & $\begin{array}{l}0.007 \\
(2.66) \\
{[2.09]}\end{array}$ & $\begin{array}{l}0.002 \\
(1.01) \\
{[1.30]}\end{array}$ & $\begin{array}{l}0.002 \\
(1.25)\end{array}$ & $\begin{array}{l}0.005 \\
(2.02) \\
{[1.45]}\end{array}$ & $\begin{array}{l}0.001 \\
(0.79)\end{array}$ \\
\hline$g_{i t-1}$ & $\begin{array}{l}0.014 \\
(0.94) \\
{[1.23]} \\
\end{array}$ & $\begin{array}{l}0.024 \\
(2.14) \\
{[2.94]} \\
\end{array}$ & $\begin{array}{l}0.026 \\
(2.03)\end{array}$ & $\begin{array}{l}0.001 \\
(0.04) \\
{[0.05]} \\
\end{array}$ & $\begin{array}{l}0.022 \\
(1.36)\end{array}$ \\
\hline$g d p p c_{i t-1} / 1,000$ & $\begin{array}{l}-0.029 \\
(-7.86) \\
{[-7.56]} \\
\end{array}$ & $\begin{array}{l}-0.007 \\
(-2.06) \\
{[-2.16]} \\
\end{array}$ & $\begin{array}{c}0.022 \\
(0.3)\end{array}$ & $\begin{array}{l}-0.031 \\
(-8.62) \\
{[-8.42]} \\
\end{array}$ & $\begin{array}{l}-0.006 \\
(-0.98)\end{array}$ \\
\hline$c p_{i t}$ & $\begin{array}{l}-0.007 \\
(-0.08) \\
{[-0.07]}\end{array}$ & $\begin{array}{l}0.042 \\
(0.73) \\
{[1.48]} \\
\end{array}$ & $\begin{array}{l}0.021 \\
(0.3)\end{array}$ & $\begin{array}{l}-0.202 \\
(-1.90) \\
{[-1.64]} \\
\end{array}$ & $\begin{array}{l}-0.024 \\
(-0.29)\end{array}$ \\
\hline contrib $_{i t}$ & $\begin{array}{c}0.062 \\
(2.6) \\
{[1.93]} \\
\end{array}$ & $\begin{array}{l}0.033 \\
(1.97) \\
{[1.85]}\end{array}$ & $\begin{array}{l}0.032 \\
(1.84)\end{array}$ & $\begin{array}{c}0.094 \\
(4.2) \\
{[2.68]} \\
\end{array}$ & $\begin{array}{l}0.043 \\
(1.48)\end{array}$ \\
\hline elect $_{i t}$ & $\begin{array}{l}0.103 \\
(1.04) \\
{[1.40]}\end{array}$ & $\begin{array}{l}0.111 \\
(2.02) \\
{[2.19]}\end{array}$ & $\begin{array}{l}0.113 \\
(1.98)\end{array}$ & $\begin{array}{l}0.069 \\
(0.73) \\
{[0.92]}\end{array}$ & $\begin{array}{l}0.051 \\
(0.59)\end{array}$ \\
\hline left $t_{i t}$ & $\begin{array}{l}0.002 \\
(2.26) \\
{[1.91]} \\
\end{array}$ & $\begin{array}{l}0.001 \\
(1.89) \\
{[1.65]} \\
\end{array}$ & $\begin{array}{l}0.001 \\
(1.19)\end{array}$ & $\begin{array}{l}0.001 \\
(0.19) \\
{[0.12]}\end{array}$ & $\begin{array}{l}0.001 \\
(0.59)\end{array}$ \\
\hline$E U_{i t}$ & $\begin{array}{l}-0.471 \\
(-2.11)\end{array}$ & $\begin{array}{l}-0.329 \\
(-2.17) \\
{[-2.64]} \\
\end{array}$ & $\begin{array}{l}-0.315 \\
(-1.88)\end{array}$ & & \\
\hline $\begin{array}{l}\text { Time dummies } \\
\text { (p-value) }\end{array}$ & $\begin{array}{c}\text { yes } \\
0.000\end{array}$ & $\begin{array}{c}\text { yes } \\
0.000\end{array}$ & $\begin{array}{c}\text { yes } \\
0.000\end{array}$ & $\begin{array}{c}\text { yes } \\
0.000\end{array}$ & $\begin{array}{c}\text { yes } \\
0.000\end{array}$ \\
\hline $\begin{array}{l}\text { Time trend } \\
\text { R2 (within) }\end{array}$ & $\begin{array}{c}\text { no } \\
0.372\end{array}$ & $\begin{array}{c}\text { no } \\
0.703\end{array}$ & no & $\begin{array}{c}\text { no } \\
0.416\end{array}$ & no \\
\hline No. of countries & 27 & 27 & 27 & 25 & 25 \\
\hline No. of obs. & 439 & 436 & 436 & 347 & 331 \\
\hline
\end{tabular}

Notes: t-values in parentheses if not stated otherwise: FE: (White-Huber robust s.e.) / [Driscoll-Kraay s.e.]; LSDVc: 500 bootstrap replications. 
Table 6: Determinants of national public investments (without contributions to the EU and political variables)

\begin{tabular}{|c|c|c|c|c|c|c|c|}
\hline & \multicolumn{4}{|c|}{ All time periods } & \multicolumn{3}{|c|}{ Only EU members } \\
\hline & $\begin{array}{l}\text { FE } \\
\text { stat. }\end{array}$ & $\begin{array}{l}\text { FE } \\
\text { dyn. }\end{array}$ & LSDVc & $\begin{array}{l}\text { SYS- } \\
\text { GMM }\end{array}$ & $\begin{array}{l}\text { FE } \\
\text { stat. }\end{array}$ & LSDVc & $\begin{array}{l}\text { SYS- } \\
\text { GMM }\end{array}$ \\
\hline & (1) & $(2)$ & (3) & (4) & (5) & (6) & (7) \\
\hline$p i n v_{i t-1}$ & & $\begin{array}{l}0.512 \\
(5.69) \\
{[6.02]} \\
\end{array}$ & $\begin{array}{c}0.678 \\
(15.54)\end{array}$ & $\begin{array}{c}0.77 \\
(8.42)\end{array}$ & & $\begin{array}{c}0.691 \\
(11.68)\end{array}$ & $\begin{array}{l}0.723 \\
(6.62)\end{array}$ \\
\hline$d_{i t-1}$ & $\begin{array}{l}-0.034 \\
(-4.09) \\
{[-10.57]}\end{array}$ & $\begin{array}{l}-0.016 \\
(-4.57) \\
{[-5.26]}\end{array}$ & $\begin{array}{l}-0.011 \\
(-3.50)\end{array}$ & $\begin{array}{l}-0.01 \\
(-2.89)\end{array}$ & $\begin{array}{l}-0.038 \\
(-4.72) \\
{[-11.27]}\end{array}$ & $\begin{array}{l}-0.012 \\
(-3.14)\end{array}$ & $\begin{array}{l}-0.012 \\
(-2.49)\end{array}$ \\
\hline$l i_{i t}$ & $\begin{array}{l}-0.02 \\
(-0.73) \\
{[-0.87]} \\
\end{array}$ & $\begin{array}{l}-0.017 \\
(-1.30) \\
{[-1.25]} \\
\end{array}$ & $\begin{array}{l}-0.018 \\
(-3.50)\end{array}$ & $\begin{array}{l}0.007 \\
(0.68)\end{array}$ & $\begin{array}{l}-0.023 \\
(-0.54) \\
{[-0.80]} \\
\end{array}$ & $\begin{array}{l}-0.016 \\
(-0.52)\end{array}$ & $\begin{array}{l}0.017 \\
(0.98)\end{array}$ \\
\hline open $_{i t-1}$ & $\begin{array}{l}-0.001 \\
(-0.23) \\
{[-0.16]}\end{array}$ & $\begin{array}{l}-0.002 \\
(-0.65) \\
{[-0.49]}\end{array}$ & $\begin{array}{l}-0.002 \\
(-0.73)\end{array}$ & $\begin{array}{l}-0.001 \\
(-0.18)\end{array}$ & $\begin{array}{l}-0.002 \\
(-0.49) \\
{[-0.37]} \\
\end{array}$ & $\begin{array}{l}-0.003 \\
(-0.88)\end{array}$ & $\begin{array}{l}-0.001 \\
(-0.11)\end{array}$ \\
\hline$g_{i t-1}$ & $\begin{array}{l}0.022 \\
(1.26) \\
{[2.32]}\end{array}$ & $\begin{array}{l}0.024 \\
(2.58) \\
{[2.71]}\end{array}$ & $\begin{array}{l}0.026 \\
(1.96)\end{array}$ & $\begin{array}{l}0.017 \\
(1.79)\end{array}$ & $\begin{array}{l}0.008 \\
(0.28) \\
{[0.49]}\end{array}$ & $\begin{array}{l}0.016 \\
(0.93)\end{array}$ & $\begin{array}{l}0.014 \\
(0.92)\end{array}$ \\
\hline$g d p p c_{i t-1} / 1,000$ & $\begin{array}{l}-0.022 \\
(-2.19) \\
{[-2.73]} \\
\end{array}$ & $\begin{array}{l}-0.012 \\
(-2.65) \\
{[-2.05]} \\
\end{array}$ & $\begin{array}{l}-0.009 \\
(-0.58)\end{array}$ & $\begin{array}{l}0.007 \\
(0.97)\end{array}$ & $\begin{array}{l}-0.023 \\
(-1.56) \\
{[-2.22]} \\
\end{array}$ & $\begin{array}{l}-0.006 \\
(-0.32)\end{array}$ & $\begin{array}{l}0.009 \\
(1.19)\end{array}$ \\
\hline$c p_{i t}$ & $\begin{array}{l}-0.134 \\
(-0.59) \\
{[-1.36]} \\
\end{array}$ & $\begin{array}{l}-0.047 \\
(-0.38) \\
{[-0.84]}\end{array}$ & $\begin{array}{l}-0.037 \\
(-0.48)\end{array}$ & $\begin{array}{c}0.01 \\
(0.08)\end{array}$ & $\begin{array}{l}-0.079 \\
(-0.30) \\
{[-0.67]} \\
\end{array}$ & $\begin{array}{l}0.022 \\
(0.26)\end{array}$ & $\begin{array}{l}-0.074 \\
(-0.48)\end{array}$ \\
\hline$E U_{i t}$ & $\begin{array}{l}0.367 \\
(1.18) \\
{[1.93]} \\
\end{array}$ & $\begin{array}{l}0.063 \\
(0.44) \\
{[0.67]} \\
\end{array}$ & $\begin{array}{l}0.015 \\
(0.12)\end{array}$ & $\begin{array}{l}0.029 \\
(0.52)\end{array}$ & & & \\
\hline $\begin{array}{l}\text { Time dummies } \\
\text { (p-value) } \\
\text { Time trend } \\
\text { (p-value) }\end{array}$ & $\begin{array}{c}\text { yes } \\
0.000 \\
\text { specific } \\
0.000\end{array}$ & $\begin{array}{c}\text { yes } \\
0.000 \\
\text { specific } \\
0.000\end{array}$ & $\begin{array}{c}\text { yes } \\
0.000 \\
\text { specific } \\
0.000\end{array}$ & $\begin{array}{c}\text { yes } \\
\text { (time demean) } \\
\text { no }\end{array}$ & $\begin{array}{c}\text { yes } \\
0.000 \\
\text { specific } \\
0.000\end{array}$ & $\begin{array}{c}\text { yes } \\
-0.798 \\
\text { specific } \\
-0.955\end{array}$ & $\begin{array}{c}\text { yes } \\
\text { (time demean) } \\
\text { no }\end{array}$ \\
\hline No. instrum. & & & & 33 & & & 32 \\
\hline Hansen (p-value) & & & & 0.777 & & & 0.923 \\
\hline $\begin{array}{l}\mathrm{AR}(2) \text { test (p-value) } \\
\mathrm{R} 2 \text { (within) }\end{array}$ & 0.689 & 0.779 & & 0.27 & 0.647 & & 0.999 \\
\hline No. of countries & 27 & 27 & 27 & 27 & 27 & 25 & 27 \\
\hline No. of obs. & 466 & 463 & 463 & 435 & 374 & 356 & 362 \\
\hline
\end{tabular}

Notes: t-values in parentheses if not stated otherwise: FE: (White-Huber robust s.e.) / [Driscoll-Kraay s.e.]; LSDVc: 500 bootstrap replications. 
Table 7: Determinants of national public investments (lagged CF variable)

\begin{tabular}{|c|c|c|c|c|c|c|c|}
\hline & \multicolumn{4}{|c|}{ All time periods } & \multicolumn{3}{|c|}{ Only EU members } \\
\hline & $\begin{array}{l}\text { FE } \\
\text { stat. }\end{array}$ & $\begin{array}{l}\text { FE } \\
\text { dyn. }\end{array}$ & LSDVc & $\begin{array}{l}\text { SYS- } \\
\text { GMM }\end{array}$ & $\begin{array}{l}\text { FE } \\
\text { stat. }\end{array}$ & LSDVc & $\begin{array}{l}\text { SYS- } \\
\text { GMM }\end{array}$ \\
\hline & $(1)$ & $(2)$ & (3) & (4) & $(5)$ & (6) & (7) \\
\hline $\operatorname{pinv}_{i t-1}$ & & $\begin{array}{l}0.462 \\
(7.11) \\
{[4.91]} \\
\end{array}$ & $\begin{array}{c}0.624 \\
(13.85)\end{array}$ & $\begin{array}{l}0.792 \\
(5.13)\end{array}$ & & $\begin{array}{c}0.636 \\
(10.49)\end{array}$ & $\begin{array}{l}0.518 \\
(3.48)\end{array}$ \\
\hline$d_{i t-1}$ & $\begin{array}{c}-0.038 \\
(-10.42) \\
{[-11.54]}\end{array}$ & $\begin{array}{l}-0.02 \\
(-5.92) \\
{[-5.83]}\end{array}$ & $\begin{array}{l}-0.015 \\
(-4.59)\end{array}$ & $\begin{array}{l}-0.005 \\
(-0.53)\end{array}$ & $\begin{array}{l}-0.041 \\
(-11.01) \\
{[-11.11]}\end{array}$ & $\begin{array}{l}-0.017 \\
(.3 .91)\end{array}$ & $\begin{array}{l}-0.015 \\
(-3.34)\end{array}$ \\
\hline$l i_{i t}$ & $\begin{array}{l}-0.022 \\
(-1.53) \\
{[-1.05]} \\
\end{array}$ & $\begin{array}{l}-0.019 \\
(-1.66) \\
{[-1.33]} \\
\end{array}$ & $\begin{array}{l}-0.02 \\
(-0.96)\end{array}$ & $\begin{array}{l}0.011 \\
(0.46)\end{array}$ & $\begin{array}{l}-0.013 \\
(0.729 \\
{[-0.47]} \\
\end{array}$ & $\begin{array}{l}-0.012 \\
(-0.38)\end{array}$ & $\begin{array}{l}0.031 \\
(1.01)\end{array}$ \\
\hline open $_{i t-1}$ & $\begin{array}{l}0.005 \\
(1.29) \\
{[1.26]} \\
\end{array}$ & $\begin{array}{c}0.002 \\
(0.6) \\
{[0.77]} \\
\end{array}$ & $\begin{array}{l}0.002 \\
(0.64)\end{array}$ & $\begin{array}{l}0.002 \\
(0.39)\end{array}$ & $\begin{array}{l}0.005 \\
(0.98) \\
{[0.90]} \\
\end{array}$ & $\begin{array}{l}0.001 \\
(0.23)\end{array}$ & $\begin{array}{l}0.001 \\
(0.37)\end{array}$ \\
\hline$g_{i t-1}$ & $\begin{array}{l}0.016 \\
(1.28) \\
{[1.77]}\end{array}$ & $\begin{array}{l}0.020 \\
(1.72) \\
{[2.07]}\end{array}$ & $\begin{array}{l}0.021 \\
(1.52)\end{array}$ & $\begin{array}{l}-0.01 \\
(-0.40)\end{array}$ & $\begin{array}{c}0.002 \\
(0.1) \\
{[0.12]}\end{array}$ & $\begin{array}{c}0.011 \\
(0.6)\end{array}$ & $\begin{array}{l}0.001 \\
(0.05)\end{array}$ \\
\hline$g d p p c_{i t-1} / 1,000$ & $\begin{array}{l}-0.018 \\
(-2.59) \\
{[-2.59]} \\
\end{array}$ & $\begin{array}{l}-0.011 \\
(-1.68) \\
{[-1.92]} \\
\end{array}$ & $\begin{array}{l}-0.009 \\
(-0.47)\end{array}$ & $\begin{array}{l}0.036 \\
(1.15)\end{array}$ & $\begin{array}{l}-0.017 \\
(-2.08) \\
{[-1.71]} \\
\end{array}$ & $\begin{array}{l}-0.005 \\
(-0.23)\end{array}$ & $\begin{array}{l}0.003 \\
(0.25)\end{array}$ \\
\hline$c p_{i t}$ & $\begin{array}{l}-0.122 \\
(-1.36) \\
{[-1.30]}\end{array}$ & $\begin{array}{l}-0.026 \\
(-0.38) \\
{[-0.45]}\end{array}$ & $\begin{array}{l}-0.019 \\
(-0.22)\end{array}$ & $\begin{array}{l}-0.281 \\
(-0.94)\end{array}$ & $\begin{array}{l}-0.087 \\
(-0.90) \\
{[-0.85]} \\
\end{array}$ & $\begin{array}{l}0.112 \\
(0.12)\end{array}$ & $\begin{array}{l}-0.252 \\
(-0.94)\end{array}$ \\
\hline contrib $_{i t}$ & $\begin{array}{l}0.015 \\
(0.83) \\
{[0.56]} \\
\end{array}$ & $\begin{array}{l}0.015 \\
(0.88) \\
{[0.70]}\end{array}$ & $\begin{array}{l}0.017 \\
(0.87)\end{array}$ & $\begin{array}{l}0.087 \\
(1.48)\end{array}$ & $\begin{array}{l}0.046 \\
(2.14) \\
{[1.51]} \\
\end{array}$ & $\begin{array}{l}0.035 \\
(1.68)\end{array}$ & $\begin{array}{l}0.116 \\
(2.2)\end{array}$ \\
\hline elect $_{i t}$ & $\begin{array}{c}0.03 \\
(0.48) \\
{[0.52]} \\
\end{array}$ & $\begin{array}{l}0.062 \\
(1.24) \\
{[1.34]} \\
\end{array}$ & $\begin{array}{l}0.074 \\
(1.26)\end{array}$ & $\begin{array}{l}0.122 \\
(2.32)\end{array}$ & $\begin{array}{l}-0.013 \\
(-0.20) \\
{[-0.21]} \\
\end{array}$ & $\begin{array}{l}0.028 \\
(0.36)\end{array}$ & $\begin{array}{l}0.026 \\
(0.49)\end{array}$ \\
\hline left $t_{i t}$ & $\begin{array}{l}0.002 \\
(3.32) \\
{[3.18]}\end{array}$ & $\begin{array}{l}0.001 \\
(2.45) \\
{[2.62]}\end{array}$ & $\begin{array}{l}0.001 \\
(1.43)\end{array}$ & $\begin{array}{l}0.001 \\
(0.67)\end{array}$ & $\begin{array}{c}0.003 \\
(3.7) \\
{[3.11]}\end{array}$ & $\begin{array}{l}0.001 \\
(1.75)\end{array}$ & $\begin{array}{l}0.002 \\
(2.34)\end{array}$ \\
\hline$E U_{i t}$ & $\begin{array}{l}0.194 \\
(0.93) \\
{[0.79]} \\
\end{array}$ & $\begin{array}{l}-0.077 \\
(-0.42)\end{array}$ & $\begin{array}{l}-0.141 \\
(-0.70)\end{array}$ & $\begin{array}{l}-0.555 \\
(-1.48)\end{array}$ & & & \\
\hline $\begin{array}{l}\text { Time dummies } \\
\text { (p-value) } \\
\text { Time trend } \\
\text { (p-value) }\end{array}$ & $\begin{array}{c}\text { yes } \\
0.000 \\
\text { specific } \\
0.000\end{array}$ & $\begin{array}{c}\text { yes } \\
0.000 \\
\text { specific } \\
0.000\end{array}$ & $\begin{array}{c}\text { yes } \\
0.000 \\
\text { specific } \\
0.000\end{array}$ & $\begin{array}{c}\text { yes } \\
\text { (time demean) } \\
\text { no }\end{array}$ & $\begin{array}{c}\text { yes } \\
0.000 \\
\text { specific } \\
0.000\end{array}$ & $\begin{array}{c}\text { yes } \\
0.000 \\
\text { specific } \\
0.000\end{array}$ & $\begin{array}{c}\text { yes } \\
\text { (time demean) } \\
\text { no }\end{array}$ \\
\hline No. instrum. & & & & 34 & & & 33 \\
\hline Hansen (p-value) & & & & 0.919 & & & 0.55 \\
\hline $\begin{array}{l}\mathrm{AR}(2) \text { test (p-value) } \\
\mathrm{R} 2 \text { (within) }\end{array}$ & & & & 0.382 & & & 0.619 \\
\hline $\begin{array}{l}\text { R2 (within) } \\
\text { No. of countries }\end{array}$ & $\begin{array}{c}0.691 \\
27\end{array}$ & $\begin{array}{c}0.762 \\
27\end{array}$ & 27 & 26 & $\begin{array}{c}0.679 \\
25\end{array}$ & 25 & 25 \\
\hline No. of obs. & 439 & 436 & 436 & 408 & 347 & 331 & 294 \\
\hline
\end{tabular}

Notes: t-values in parentheses if not stated otherwise: FE: (White-Huber robust s.e.) / [Driscoll-Kraay s.e.]; LSDVc: 500 bootstrap replications. 
Table 8: Determinants of national public investments (one-step firstdifferenced GMM instead of SYS-GMM)

\begin{tabular}{|c|c|c|}
\hline & All time periods & Only EU members \\
\hline & (1) & $(2)$ \\
\hline \multirow[t]{2}{*}{$\operatorname{pinv}_{i t}$} & 0.778 & 0.49 \\
\hline & $(5.26)$ & $(3.21)$ \\
\hline \multirow[t]{2}{*}{$d_{i t}$} & -0.004 & -0.014 \\
\hline & $(-0.52)$ & $(-3.32)$ \\
\hline \multirow[t]{2}{*}{$l i_{i t}$} & 0.019 & 0.032 \\
\hline & $(0.87)$ & $(1.10)$ \\
\hline \multirow[t]{2}{*}{ open $_{i t}$} & 0.002 & 0.001 \\
\hline & $(0.32)$ & $(0.21)$ \\
\hline \multirow[t]{2}{*}{$g_{i t}$} & -0.010 & -0.002 \\
\hline & $(-0.40)$ & $(-0.07)$ \\
\hline \multirow{2}{*}{$g d p p c_{i t} / 1,000$} & 0.037 & 0.001 \\
\hline & $(1.07)$ & $(0.06)$ \\
\hline \multirow[t]{2}{*}{$c p_{i t}$} & -0.473 & -0.321 \\
\hline & $(-1.29)$ & $(-0.90)$ \\
\hline \multirow[t]{2}{*}{ contrib $_{i t}$} & 0.098 & 0.104 \\
\hline & $(2.02)$ & $(2.07)$ \\
\hline \multirow[t]{2}{*}{ elect $_{i t}$} & 0.109 & 0.024 \\
\hline & $(2.20)$ & $(0.47)$ \\
\hline \multirow[t]{2}{*}{ left $t_{i t}$} & 0.000 & 0.002 \\
\hline & $(0.31)$ & $(2.33)$ \\
\hline \multirow[t]{2}{*}{$E U_{i t}$} & -0.571 & \\
\hline & $(-1.89)$ & \\
\hline Time dummies & yes & yes \\
\hline (p-value) & (time demean) & (time demean) \\
\hline Time trend & no & no \\
\hline No. instrum. & 34 & 33 \\
\hline Hansen (p-value) & 0.998 & 0.576 \\
\hline $\operatorname{AR}(2)$ test (p-value) & 0.399 & 0.509 \\
\hline No. of countries & 26 & 25 \\
\hline No. of obs. & 381 & 294 \\
\hline
\end{tabular}

Notes: t-values in parentheses if not stated otherwise. 
Table 9: Determinants of primary budget balances

\begin{tabular}{|c|c|c|c|c|c|c|c|}
\hline & \multicolumn{4}{|c|}{ All time periods } & \multicolumn{3}{|c|}{ Only EU members } \\
\hline & $\begin{array}{l}\text { FE } \\
\text { stat. }\end{array}$ & $\begin{array}{l}\text { FE } \\
\text { dyn. }\end{array}$ & LSDVc & $\begin{array}{l}\text { SYS- } \\
\text { GMM }\end{array}$ & $\begin{array}{l}\text { FE } \\
\text { stat. }\end{array}$ & LSDVc & $\begin{array}{l}\text { SYS- } \\
\text { GMM }\end{array}$ \\
\hline & (1) & $(2)$ & (3) & (4) & $(5)$ & (6) & (7) \\
\hline bal $_{i t-1}$ & & $\begin{array}{c}0.561 \\
(11.01) \\
{[7.14]} \\
\end{array}$ & $\begin{array}{c}0.725 \\
(15.33)\end{array}$ & $\begin{array}{l}0.765 \\
(9.13)\end{array}$ & & $\begin{array}{c}0.754 \\
(12.84)\end{array}$ & $\begin{array}{l}0.729 \\
(6.09)\end{array}$ \\
\hline$d_{i t-1}$ & $\begin{array}{l}0.088 \\
(4.07) \\
{[4.71]}\end{array}$ & $\begin{array}{l}0.073 \\
(4.51) \\
{[5.09]}\end{array}$ & $\begin{array}{l}0.063 \\
(3.83)\end{array}$ & $\begin{array}{l}0.010 \\
(0.29)\end{array}$ & $\begin{array}{c}0.128 \\
(6.91) \\
{[11.49]}\end{array}$ & $\begin{array}{l}0.067 \\
(3.62)\end{array}$ & $\begin{array}{l}0.016 \\
(0.40)\end{array}$ \\
\hline$l i_{i t}$ & $\begin{array}{l}0.130 \\
(1.16) \\
{[1.20]} \\
\end{array}$ & $\begin{array}{c}0.168 \\
(1.4) \\
{[1.65]} \\
\end{array}$ & $\begin{array}{l}0.198 \\
(1.68)\end{array}$ & $\begin{array}{l}0.108 \\
(1.32)\end{array}$ & $\begin{array}{l}0.166 \\
(1.22) \\
{[1.54]} \\
\end{array}$ & $\begin{array}{l}0.288 \\
(2.14)\end{array}$ & $\begin{array}{l}0.058 \\
(0.63)\end{array}$ \\
\hline open $_{i t-1}$ & $\begin{array}{l}-0.035 \\
(-2.41) \\
{[-2.05]} \\
\end{array}$ & $\begin{array}{l}-0.027 \\
(-2.17) \\
{[-2.63]} \\
\end{array}$ & $\begin{array}{l}-0.030 \\
(-2.11)\end{array}$ & $\begin{array}{l}0.011 \\
(0.82)\end{array}$ & $\begin{array}{l}-0.014 \\
(-0.95) \\
{[-1.07]} \\
\end{array}$ & $\begin{array}{l}-0.020 \\
(-1.24)\end{array}$ & $\begin{array}{l}0.005 \\
(0.39)\end{array}$ \\
\hline$g_{i t-1}$ & $\begin{array}{l}0.270 \\
(3.61) \\
{[4.59]}\end{array}$ & $\begin{array}{l}0.213 \\
(3.09) \\
{[3.95]}\end{array}$ & $\begin{array}{l}0.207 \\
(3.66)\end{array}$ & $\begin{array}{l}0.141 \\
(0.96)\end{array}$ & $\begin{array}{l}0.074 \\
(0.83) \\
{[1.17]}\end{array}$ & $\begin{array}{l}0.120 \\
(1.69)\end{array}$ & $\begin{array}{l}0.201 \\
(2.53)\end{array}$ \\
\hline$g d p p c_{i t-1} / 1,000$ & $\begin{array}{l}-0.031 \\
(-0.41) \\
{[-0.51]} \\
\end{array}$ & $\begin{array}{l}-0.071 \\
(-0.72) \\
{[-0.91]} \\
\end{array}$ & $\begin{array}{l}-0.109 \\
(-0.93)\end{array}$ & $\begin{array}{l}-0.161 \\
(-1.39)\end{array}$ & $\begin{array}{l}-0.092 \\
(-1.38) \\
{[-1.25]} \\
\end{array}$ & $\begin{array}{l}-0.120 \\
(-1.02)\end{array}$ & $\begin{array}{l}-0.043 \\
(-0.54)\end{array}$ \\
\hline$c p_{i t}$ & $\begin{array}{l}1.510 \\
(5.07) \\
{[6.80]} \\
\end{array}$ & $\begin{array}{l}0.620 \\
(1.92) \\
{[2.39]} \\
\end{array}$ & $\begin{array}{l}0.425 \\
(1.07)\end{array}$ & $\begin{array}{r}-1.610 \\
(1.39)\end{array}$ & $\begin{array}{l}1.289 \\
(4.17) \\
{[7.19]} \\
\end{array}$ & $\begin{array}{l}0.138 \\
(0.37)\end{array}$ & $\begin{array}{r}-0.090 \\
(1.01)\end{array}$ \\
\hline contrib $_{i t}$ & $\begin{array}{l}0.184 \\
(1.63) \\
{[1.92]} \\
\end{array}$ & $\begin{array}{l}0.060 \\
(0.79) \\
{[0.59]} \\
\end{array}$ & $\begin{array}{c}0.0270 \\
(0.31)\end{array}$ & $\begin{array}{r}-0.217 \\
(0.66)\end{array}$ & $\begin{array}{l}0.090 \\
(0.71) \\
{[1.05]} \\
\end{array}$ & $\begin{array}{l}0.030 \\
(0.27)\end{array}$ & $\begin{array}{l}0.109 \\
(0.65)\end{array}$ \\
\hline elect $_{i t}$ & $\begin{array}{l}-0.253 \\
(-0.80) \\
{[-0.94]} \\
\end{array}$ & $\begin{array}{l}-0.636 \\
(-2.65) \\
{[-4.23]} \\
\end{array}$ & $\begin{array}{l}-0.726 \\
(-2.49)\end{array}$ & $\begin{array}{l}-0.990 \\
(-3.68)\end{array}$ & $\begin{array}{l}0.002 \\
(0.01) \\
{[0.01]} \\
\end{array}$ & $\begin{array}{l}-0.436 \\
(-1.33)\end{array}$ & $\begin{array}{l}-0.695 \\
(-3.00)\end{array}$ \\
\hline left $t_{i t}$ & $\begin{array}{c}0.000 \\
(-0.04) \\
{[-0.03]}\end{array}$ & $\begin{array}{l}-0.005 \\
(-1.65) \\
{[-1.58]}\end{array}$ & $\begin{array}{l}-0.005 \\
(-1.31)\end{array}$ & $\begin{array}{l}0.001 \\
(0.15)\end{array}$ & $\begin{array}{l}-0.008 \\
(-1.80) \\
{[-1.29]}\end{array}$ & $\begin{array}{l}-0.007 \\
(-1.93)\end{array}$ & $\begin{array}{l}0.001 \\
(0.23)\end{array}$ \\
\hline$E U_{i t}$ & $\begin{array}{l}-0.750 \\
(-0.68) \\
{[-0.58]} \\
\end{array}$ & $\begin{array}{l}-0.002 \\
(-0.00) \\
{[-0.00]} \\
\end{array}$ & & & & & \\
\hline $\begin{array}{l}\text { Time dummies } \\
\text { (p-value) } \\
\text { Time trend } \\
\text { (p-value) }\end{array}$ & $\begin{array}{c}\text { yes } \\
0.000 \\
\text { specific } \\
0.000\end{array}$ & $\begin{array}{c}\text { yes } \\
0.000 \\
\text { specific } \\
0.000\end{array}$ & $\begin{array}{c}\text { yes } \\
0.000 \\
\text { specific } \\
0.000\end{array}$ & $\begin{array}{c}\text { yes } \\
\text { (time demean) } \\
\text { no }\end{array}$ & $\begin{array}{c}\text { yes } \\
0.000 \\
\text { specific } \\
0.000\end{array}$ & $\begin{array}{c}\text { yes } \\
0.000 \\
\text { specific } \\
0.000\end{array}$ & $\begin{array}{c}\text { yes } \\
\text { (time demean) } \\
\text { no }\end{array}$ \\
\hline No. instrum. & & & & 35 & & & 34 \\
\hline Hansen (p-value) & & & & 0.725 & & & 0.892 \\
\hline $\begin{array}{l}\mathrm{AR}(2) \text { test (p-value) } \\
\mathrm{R} 2 \text { (within) }\end{array}$ & & & & 0.539 & & & 0.738 \\
\hline $\begin{array}{l}\text { R2 (within) } \\
\text { No. of countries }\end{array}$ & $\begin{array}{c}0.588 \\
27\end{array}$ & $\begin{array}{c}0.735 \\
27\end{array}$ & 27 & 26 & $\begin{array}{c}0.661 \\
25\end{array}$ & 25 & 25 \\
\hline No. of obs. & 406 & 400 & 400 & 373 & 329 & 311 & 300 \\
\hline
\end{tabular}

Notes: t-values in parentheses if not stated otherwise: FE: (White-Huber robust s.e.) / [Driscoll-Kraay s.e.]; LSDVc: 500 bootstrap replications. 
Table 10: Determinants of primary budget balances (without countryspecific time trend)

\begin{tabular}{|c|c|c|c|c|c|}
\hline & \multicolumn{3}{|c|}{ All time periods } & \multicolumn{2}{|c|}{ Only EU members } \\
\hline & $\begin{array}{l}\text { FE } \\
\text { stat. }\end{array}$ & $\begin{array}{l}\text { FE } \\
\text { dyn. }\end{array}$ & LSDVc & $\begin{array}{c}\text { FE } \\
\text { stat. }\end{array}$ & LSDVc \\
\hline & (1) & $(2)$ & (3) & $(4)$ & (5) \\
\hline bal $_{i t-1}$ & & $\begin{array}{c}0.670 \\
(17.43) \\
{[12.41]}\end{array}$ & $\begin{array}{c}0.768 \\
(20.45)\end{array}$ & & $\begin{array}{c}0.811 \\
(16.98)\end{array}$ \\
\hline$d_{i t-1}$ & $\begin{array}{l}0.014 \\
(1.21) \\
{[0.91]}\end{array}$ & $\begin{array}{l}0.022 \\
(3.05) \\
{[2.98]}\end{array}$ & $\begin{array}{l}0.022 \\
(2.41)\end{array}$ & $\begin{array}{c}0.026 \\
(2.2) \\
{[1.41]}\end{array}$ & $\begin{array}{l}0.024 \\
(2.87)\end{array}$ \\
\hline$l i_{i t}$ & $\begin{array}{l}0.058 \\
(0.61) \\
{[0.48]}\end{array}$ & $\begin{array}{l}0.084 \\
(1.07) \\
{[1.13]}\end{array}$ & $\begin{array}{l}0.104 \\
(1.58)\end{array}$ & $\begin{array}{l}0.101 \\
(0.88) \\
{[0.71]}\end{array}$ & $\begin{array}{l}0.196 \\
(2.46)\end{array}$ \\
\hline open $_{i t-1}$ & $\begin{array}{l}0.002 \\
(0.23) \\
{[0.22]}\end{array}$ & $\begin{array}{l}-0.004 \\
(-0.49) \\
{[-0.52]}\end{array}$ & $\begin{array}{l}-0.004 \\
(-0.44)\end{array}$ & $\begin{array}{l}0.009 \\
(0.83) \\
{[0.79]}\end{array}$ & $\begin{array}{l}0.001 \\
(0.06)\end{array}$ \\
\hline$g_{i t-1}$ & $\begin{array}{l}0.345 \\
(4.69) \\
{[4.23]}\end{array}$ & $\begin{array}{l}0.178 \\
(2.68) \\
{[3.08]}\end{array}$ & $\begin{array}{l}0.169 \\
(3.54)\end{array}$ & $\begin{array}{l}0.182 \\
(2.04) \\
{[1.86]}\end{array}$ & $\begin{array}{l}0.108 \\
(1.87)\end{array}$ \\
\hline$g d p p c_{i t-1} / 1,000$ & $\begin{array}{c}-0.02 \\
(-0.30) \\
{[-0.29]}\end{array}$ & $\begin{array}{l}0.003 \\
(0.05) \\
{[0.06]}\end{array}$ & $\begin{array}{l}-0.124 \\
(-0.20)\end{array}$ & $\begin{array}{l}-0.052 \\
(-0.75) \\
{[-0.69]}\end{array}$ & $\begin{array}{l}-0.051 \\
(-0.79)\end{array}$ \\
\hline$c p_{i t}$ & $\begin{array}{l}0.916 \\
(2.64) \\
{[2.96]}\end{array}$ & $\begin{array}{l}0.290 \\
(1.05) \\
{[1.33]}\end{array}$ & $\begin{array}{l}0.316 \\
(1.00)\end{array}$ & $\begin{array}{l}0.581 \\
(1.50) \\
{[1.94]}\end{array}$ & $\begin{array}{l}-0.263 \\
(-0.86)\end{array}$ \\
\hline contrib $_{i t}$ & $\begin{array}{c}0.199 \\
(1.8) \\
{[1.44]}\end{array}$ & $\begin{array}{l}0.007 \\
(0.11) \\
{[0.09]}\end{array}$ & $\begin{array}{l}-0.017 \\
(-0.22)\end{array}$ & $\begin{array}{l}0.009 \\
(0.83) \\
{[1.24]}\end{array}$ & $\begin{array}{l}-0.026 \\
(-0.28)\end{array}$ \\
\hline elect $_{i t}$ & $\begin{array}{l}-0.341 \\
(-0.96) \\
{[-1.12]}\end{array}$ & $\begin{array}{l}-0.772 \\
(-3.18) \\
{[-4.80]}\end{array}$ & $\begin{array}{l}-0.817 \\
(-2.90)\end{array}$ & $\begin{array}{l}-0.232 \\
(-0.64) \\
{[-0.77]}\end{array}$ & $\begin{array}{l}-0.57 \\
(-1.84)\end{array}$ \\
\hline left $t_{i t}$ & $\begin{array}{l}0.001 \\
(0.13) \\
{[0.08]} \\
\end{array}$ & $\begin{array}{l}-0.003 \\
(-1.42) \\
{[-1.27]}\end{array}$ & $\begin{array}{l}-0.004 \\
(-1.49)\end{array}$ & $\begin{array}{l}-0.004 \\
(-1.01) \\
{[-0.90]}\end{array}$ & $\begin{array}{l}-0.004 \\
(-1.25)\end{array}$ \\
\hline$E U_{i t}$ & $\begin{array}{l}-1.217 \\
(2.64) \\
{[-0.88]}\end{array}$ & $\begin{array}{l}0.158 \\
(0.23) \\
{[0.20]}\end{array}$ & $\begin{array}{l}0.346 \\
(0.49)\end{array}$ & & \\
\hline $\begin{array}{l}\text { Time dummies } \\
\text { (p-value) }\end{array}$ & $\begin{array}{c}\text { yes } \\
0.000\end{array}$ & $\begin{array}{c}\text { yes } \\
0.000\end{array}$ & $\begin{array}{c}\text { yes } \\
0.000\end{array}$ & $\begin{array}{c}\text { yes } \\
0.000\end{array}$ & $\begin{array}{c}\text { yes } \\
0.000\end{array}$ \\
\hline $\begin{array}{l}\text { Time trend } \\
\text { R2 (within) }\end{array}$ & $\begin{array}{c}\text { no } \\
0.3526\end{array}$ & $\begin{array}{c}\text { no } \\
0.683\end{array}$ & no & $\begin{array}{c}\text { no } \\
0.3608\end{array}$ & no \\
\hline No. of countries & 27 & 27 & 27 & 25 & 25 \\
\hline No. of obs. & 406 & 400 & 400 & 329 & 311 \\
\hline
\end{tabular}

Notes: t-values in parentheses if not stated otherwise: FE: (White-Huber robust s.e.) / [Driscoll-Kraay s.e.]; LSDVc: 500 bootstrap replications. 
Table 11: Determinants of primary budget balances (without contributions to the EU and political variables)

\begin{tabular}{|c|c|c|c|c|c|c|c|}
\hline & \multicolumn{4}{|c|}{ All time periods } & \multicolumn{3}{|c|}{ Only EU members } \\
\hline & $\begin{array}{l}\text { FE } \\
\text { stat. }\end{array}$ & $\begin{array}{l}\text { FE } \\
\text { dyn. }\end{array}$ & LSDVc & $\begin{array}{l}\text { SYS- } \\
\text { GMM }\end{array}$ & $\begin{array}{l}\text { FE } \\
\text { stat. }\end{array}$ & LSDVc & $\begin{array}{l}\text { SYS- } \\
\text { GMM }\end{array}$ \\
\hline & (1) & $(2)$ & (3) & $(4)$ & (5) & (6) & (7) \\
\hline$b_{i t-1}$ & & $\begin{array}{l}0.551 \\
(6.46) \\
{[7.20]}\end{array}$ & $\begin{array}{c}0.708 \\
(15.67)\end{array}$ & $\begin{array}{c}0.779 \\
(10.78)\end{array}$ & & $\begin{array}{c}0.732 \\
(13.29)\end{array}$ & $\begin{array}{c}0.73 \\
(8.03)\end{array}$ \\
\hline$d_{i t-1}$ & $\begin{array}{l}0.088 \\
(2.28) \\
{[-5.03]} \\
\end{array}$ & $\begin{array}{l}0.067 \\
(3.41) \\
{[-4.59]} \\
\end{array}$ & $\begin{array}{l}0.056 \\
(3.62)\end{array}$ & $\begin{array}{c}0.03 \\
(1.39)\end{array}$ & $\begin{array}{l}0.119 \\
(7.08) \\
{[-9.80]} \\
\end{array}$ & $\begin{array}{l}0.059 \\
(3.83)\end{array}$ & $\begin{array}{l}0.063 \\
(1.78)\end{array}$ \\
\hline$l i_{i t}$ & $\begin{array}{l}0.104 \\
(0.95) \\
{[-0.96]}\end{array}$ & $\begin{array}{c}0.11 \\
(0.94) \\
{[-1.13]}\end{array}$ & $\begin{array}{l}0.144 \\
(1.51)\end{array}$ & $\begin{array}{l}0.024 \\
(0.52)\end{array}$ & $\begin{array}{l}0.198 \\
(1.61) \\
{[-0.28]}\end{array}$ & $\begin{array}{l}0.302 \\
(2.41)\end{array}$ & $\begin{array}{l}-0.031 \\
(-0.40)\end{array}$ \\
\hline open $_{i t-1}$ & $\begin{array}{l}-0.024 \\
(-0.78) \\
{[-1.16]} \\
\end{array}$ & $\begin{array}{l}-0.011 \\
(-0.72) \\
{[-0.79]} \\
\end{array}$ & $\begin{array}{l}-0.013 \\
(-1.00)\end{array}$ & $\begin{array}{l}0.011 \\
(0.95)\end{array}$ & $\begin{array}{l}0.004 \\
(0.28) \\
{[-0.28]} \\
\end{array}$ & $\begin{array}{l}0.001 \\
(0.04)\end{array}$ & $\begin{array}{l}0.007 \\
(0.45)\end{array}$ \\
\hline$g_{i t-1}$ & $\begin{array}{l}0.286 \\
(2.28) \\
{[-4.42]}\end{array}$ & $\begin{array}{l}0.199 \\
(2.46) \\
{[-3.52]}\end{array}$ & $\begin{array}{c}0.19 \\
(3.29)\end{array}$ & $\begin{array}{l}0.171 \\
(1.63)\end{array}$ & $\begin{array}{l}0.092 \\
(1.05) \\
{[-1.33]}\end{array}$ & $\begin{array}{l}0.116 \\
(1.57)\end{array}$ & $\begin{array}{c}0.15 \\
(1.41)\end{array}$ \\
\hline$g d p p c_{i t-1} / 1,000$ & $\begin{array}{l}-0.014 \\
(-0.11) \\
{[-0.20]} \\
\end{array}$ & $\begin{array}{l}-0.012 \\
(-0.15) \\
{[-0.16]} \\
\end{array}$ & $\begin{array}{l}-0.05 \\
(-0.51)\end{array}$ & $\begin{array}{l}-0.114 \\
(-1.22)\end{array}$ & $\begin{array}{l}-0.105 \\
(-1.77) \\
{[-1.51]} \\
\end{array}$ & $\begin{array}{l}-0.103 \\
(-0.92)\end{array}$ & $\begin{array}{l}-0.001 \\
(-0.01)\end{array}$ \\
\hline$c p_{i t}$ & $\begin{array}{l}1.537 \\
(3.78) \\
{[-6.58]}\end{array}$ & $\begin{array}{l}0.711 \\
(3.40) \\
{[-2.92]}\end{array}$ & $\begin{array}{l}0.528 \\
(1.68\end{array}$ & $\begin{array}{l}-1.291 \\
(-1.48)\end{array}$ & $\begin{array}{c}1.25 \\
(4.32 \\
{[-5.74]}\end{array}$ & $\begin{array}{l}0.182 \\
(0.53\end{array}$ & $\begin{array}{l}-0.509 \\
(-0.48)\end{array}$ \\
\hline$E U_{i t}$ & $\begin{array}{l}0.656 \\
(1.12) \\
{[-1.02]}\end{array}$ & $\begin{array}{l}0.258 \\
(0.46) \\
{[-0.64]}\end{array}$ & $\begin{array}{c}0.15 \\
(-0.29)\end{array}$ & $\begin{array}{c}1.45 \\
(-1.55)\end{array}$ & & & \\
\hline $\begin{array}{l}\text { Time dummies } \\
\text { (p-values) } \\
\text { Time trend } \\
\text { (p-values) }\end{array}$ & $\begin{array}{c}\text { yes } \\
0 \\
\text { specific } \\
0\end{array}$ & $\begin{array}{c}\text { yes } \\
0 \\
\text { specific } \\
0\end{array}$ & $\begin{array}{c}\text { yes } \\
0 \\
\text { specific } \\
-0.248\end{array}$ & $\begin{array}{c}\text { yes } \\
\text { (time demean) } \\
\text { no }\end{array}$ & $\begin{array}{c}\text { yes } \\
0 \\
\text { specific } \\
0\end{array}$ & $\begin{array}{c}\text { yes } \\
0 \\
\text { specific } \\
-0.929\end{array}$ & $\begin{array}{c}\text { yes } \\
\text { (time demean) } \\
\text { no }\end{array}$ \\
\hline No. instruments & & & & 29 & & & 28 \\
\hline Hansen (p-value) & & & & 0.503 & & & 0.343 \\
\hline $\begin{array}{l}\mathrm{AR}(2) \text { test (p-value) } \\
\mathrm{R} 2 \text { (within) }\end{array}$ & 0.57 & 0.717 & & 0.743 & 0.641 & & 0.629 \\
\hline No. of countries & 27 & 27 & 27 & 27 & 27 & 25 & 27 \\
\hline No. of obs. & 433 & 427 & 427 & 400 & 356 & 336 & 325 \\
\hline
\end{tabular}

Notes: t-values in parentheses if not stated otherwise: FE: (White-Huber robust s.e.) / [Driscoll-Kraay s.e.]; LSDVc: 500 bootstrap replications. 
Table 12: Determinants of primary budget balances (lagged CF variable)

\begin{tabular}{|c|c|c|c|c|c|c|c|}
\hline & \multicolumn{4}{|c|}{ All time periods } & \multicolumn{3}{|c|}{ Only EU members } \\
\hline & $\begin{array}{l}\text { FE } \\
\text { stat. }\end{array}$ & $\begin{array}{l}\text { FE } \\
\text { dyn. }\end{array}$ & LSDVc & $\begin{array}{l}\text { SYS- } \\
\text { GMM }\end{array}$ & $\begin{array}{l}\text { FE } \\
\text { stat. }\end{array}$ & LSDVc & $\begin{array}{l}\text { SYS- } \\
\text { GMM }\end{array}$ \\
\hline & $(1)$ & $(2)$ & (3) & $(4)$ & $(5)$ & $(6)$ & $(7)$ \\
\hline bal $_{i t-1}$ & & $\begin{array}{c}0.568 \\
(11.00) \\
{[7.68]} \\
\end{array}$ & $\begin{array}{c}0.733 \\
(15.28)\end{array}$ & $\begin{array}{l}0.686 \\
(7.76)\end{array}$ & & $\begin{array}{c}0.76 \\
(13.01)\end{array}$ & $\begin{array}{l}0.627 \\
(8.62)\end{array}$ \\
\hline$d_{i t-1}$ & $\begin{array}{c}0.09 \\
(4.18) \\
{[4.83]}\end{array}$ & $\begin{array}{l}0.072 \\
(4.38) \\
{[5.13]}\end{array}$ & $\begin{array}{c}0.06 \\
(3.63)\end{array}$ & $\begin{array}{l}0.079 \\
(1.8)\end{array}$ & $\begin{array}{l}0.129 \\
(6.92) \\
{[11.44]}\end{array}$ & $\begin{array}{l}0.064 \\
(3.37)\end{array}$ & $\begin{array}{c}0.09 \\
(2.76)\end{array}$ \\
\hline$l i_{i t}$ & $\begin{array}{c}0.13 \\
(1.18) \\
{[1.14]} \\
\end{array}$ & $\begin{array}{l}0.147 \\
(1.23) \\
{[1.45]} \\
\end{array}$ & $\begin{array}{l}0.177 \\
(1.53)\end{array}$ & $\begin{array}{l}-0.001 \\
(0.01)\end{array}$ & $\begin{array}{l}0.187 \\
(1.38) \\
{[1.70]} \\
\end{array}$ & $\begin{array}{l}0.275 \\
(2.00)\end{array}$ & $\begin{array}{r}-0.051 \\
(0.38)\end{array}$ \\
\hline open $_{i t-1}$ & $\begin{array}{l}-0.04 \\
(-2.64) \\
{[-2.22]} \\
\end{array}$ & $\begin{array}{l}-0.029 \\
(-2.27) \\
{[-2.81]} \\
\end{array}$ & $\begin{array}{l}-0.03 \\
(-2.13)\end{array}$ & $\begin{array}{l}-0.021 \\
(-1.02)\end{array}$ & $\begin{array}{l}-0.02 \\
(-1.33) \\
{[-1.39]} \\
\end{array}$ & $\begin{array}{l}-0.019 \\
(-1.21)\end{array}$ & $\begin{array}{l}-0.026 \\
(-1.62)\end{array}$ \\
\hline$g_{i t-1}$ & $\begin{array}{l}0.283 \\
(3.71) \\
{[4.10]}\end{array}$ & $\begin{array}{l}0.221 \\
(3.13) \\
{[3.84]}\end{array}$ & $\begin{array}{l}0.216 \\
(3.79)\end{array}$ & $\begin{array}{c}0.03 \\
(0.29)\end{array}$ & $\begin{array}{c}0.1 \\
(1.13) \\
{[1.59]}\end{array}$ & $\begin{array}{l}0.129 \\
(1.84)\end{array}$ & $\begin{array}{l}0.069 \\
(0.70)\end{array}$ \\
\hline$g d p p c_{i t-1} / 1,000$ & $\begin{array}{l}-0.042 \\
(-0.52) \\
{[-0.66]} \\
\end{array}$ & $\begin{array}{l}-0.077 \\
(-0.77) \\
{[-0.96]} \\
\end{array}$ & $\begin{array}{l}-0.124 \\
(-1.03)\end{array}$ & $\begin{array}{l}-0.095 \\
(-0.45)\end{array}$ & $\begin{array}{l}-0.098 \\
(-1.40) \\
{[-1.22]} \\
\end{array}$ & $\begin{array}{l}-0.132 \\
(-1.12)\end{array}$ & $\begin{array}{l}0.009 \\
-0.08\end{array}$ \\
\hline$c p_{i t}$ & $\begin{array}{l}1.181 \\
(3.24) \\
{[3.63]} \\
\end{array}$ & $\begin{array}{l}0.264 \\
(0.79) \\
{[1.27]} \\
\end{array}$ & $\begin{array}{l}0.083 \\
(0.21)\end{array}$ & $\begin{array}{l}-0.844 \\
(-0.61)\end{array}$ & $\begin{array}{l}1.023 \\
(2.97) \\
{[3.60]} \\
\end{array}$ & $\begin{array}{l}-0.091 \\
(-0.23)\end{array}$ & $\begin{array}{c}-0.308 \\
(-0.8)\end{array}$ \\
\hline contrib $_{i t}$ & $\begin{array}{l}0.169 \\
(1.46) \\
{[1.82]}\end{array}$ & $\begin{array}{l}0.065 \\
(0.83) \\
{[0.60]}\end{array}$ & $\begin{array}{l}0.036 \\
(0.41)\end{array}$ & $\begin{array}{l}-0.403 \\
(-1.76)\end{array}$ & $\begin{array}{l}0.072 \\
(0.56) \\
{[0.81]}\end{array}$ & $\begin{array}{l}0.039 \\
(0.35)\end{array}$ & $\begin{array}{l}-0.549 \\
(-1.99)\end{array}$ \\
\hline elect $_{i t}$ & $\begin{array}{l}-0.269 \\
(-0.85) \\
{[-0.95]} \\
\end{array}$ & $\begin{array}{l}-0.634 \\
(-2.62) \\
{[-4.18]} \\
\end{array}$ & $\begin{array}{l}-0.72 \\
(-2.48)\end{array}$ & $\begin{array}{l}-0.998 \\
(-3.74)\end{array}$ & $\begin{array}{l}0.057 \\
(0.18) \\
{[0.22]} \\
\end{array}$ & $\begin{array}{l}-0.426 \\
(-1.32)\end{array}$ & $\begin{array}{l}-0.614 \\
(-2.78)\end{array}$ \\
\hline left $t_{i t}$ & $\begin{array}{l}-0.002 \\
(-0.40) \\
{[-0.30]}\end{array}$ & $\begin{array}{l}-0.006 \\
(-1.84) \\
{[-1.74]}\end{array}$ & $\begin{array}{l}-0.005 \\
(-1.34)\end{array}$ & $\begin{array}{l}0.002 \\
(0.48)\end{array}$ & $\begin{array}{l}-0.009 \\
(-1.95) \\
{[-2.02]}\end{array}$ & $\begin{array}{l}-0.007 \\
(-1.89)\end{array}$ & $\begin{array}{l}-0.001 \\
(-0.24)\end{array}$ \\
\hline$E U_{i t}$ & $\begin{array}{l}-0.391 \\
(-0.35) \\
{[-0.51]} \\
\end{array}$ & $\begin{array}{l}0.055 \\
(0.06) \\
{[0.05]} \\
\end{array}$ & & $\begin{array}{l}4.208 \\
(2.27)\end{array}$ & & & \\
\hline $\begin{array}{l}\text { Time dummies } \\
\text { (p-value) } \\
\text { Time trend } \\
\text { (p-value) }\end{array}$ & $\begin{array}{c}\text { yes } \\
0.000 \\
\text { specific } \\
0.000\end{array}$ & $\begin{array}{c}\text { yes } \\
0.000 \\
\text { specific } \\
0.000\end{array}$ & $\begin{array}{c}\text { yes } \\
0.000 \\
\text { specific } \\
0.000\end{array}$ & $\begin{array}{c}\text { yes } \\
\text { (time demean) } \\
\text { no }\end{array}$ & $\begin{array}{c}\text { yes } \\
0.000 \\
\text { specific } \\
0.000\end{array}$ & $\begin{array}{c}\text { yes } \\
0.000 \\
\text { specific } \\
0.000\end{array}$ & $\begin{array}{c}\text { yes } \\
\text { (time demean) } \\
\text { no }\end{array}$ \\
\hline No. instrum. & & & & 35 & & & 34 \\
\hline Hansen (p-value) & & & & 0.823 & & & 0.743 \\
\hline $\begin{array}{l}\mathrm{AR}(2) \text { test (p-value) } \\
\mathrm{R} 2 \text { (within) }\end{array}$ & 0.580 & 0.732 & & 0.313 & 0.656 & & 0.555 \\
\hline No. of countries & 27 & 27 & 27 & 26 & 25 & 25 & 25 \\
\hline No. of obs. & 406 & 400 & 400 & 373 & 329 & 311 & 300 \\
\hline
\end{tabular}

Notes: t-values in parentheses if not stated otherwise: FE: (White-Huber robust s.e.) / [Driscoll-Kraay s.e.]; LSDVc: 500 bootstrap replications. 
Table 13: Determinants of primary budget balances (one-step firstdifferenced GMM instead of SYS-GMM)

\begin{tabular}{|c|c|c|}
\hline & All time periods & Only EU members \\
\hline & (1) & $(2)$ \\
\hline$b_{a l-1}$ & $\begin{array}{c}0.682 \\
(7.56)\end{array}$ & $\begin{array}{c}0.62 \\
(7.77)\end{array}$ \\
\hline$d_{i t-1}$ & $\begin{array}{c}0.089 \\
(2.1)\end{array}$ & $\begin{array}{l}0.094 \\
(2.84)\end{array}$ \\
\hline$l i_{i t}$ & $\begin{array}{l}-0.031 \\
(-0.23)\end{array}$ & $\begin{array}{l}-0.064 \\
(-0.51)\end{array}$ \\
\hline open $_{i t-1}$ & $\begin{array}{l}-0.017 \\
(-0.67)\end{array}$ & $\begin{array}{l}-0.026 \\
(-1.34)\end{array}$ \\
\hline$g_{i t-1}$ & $\begin{array}{l}0.005 \\
(0.04)\end{array}$ & $\begin{array}{l}0.059 \\
(0.60)\end{array}$ \\
\hline$g d p p c_{i t-1} / 1,000$ & $\begin{array}{l}-0.156 \\
(-0.70) \\
\end{array}$ & $\begin{array}{l}-0.008 \\
(-0.06) \\
\end{array}$ \\
\hline$c p_{i t}$ & $\begin{array}{l}-0.017 \\
(-0.01)\end{array}$ & $\begin{array}{l}0.236 \\
(0.15) \\
\end{array}$ \\
\hline contrib $_{i t}$ & $\begin{array}{l}-0.589 \\
(-2.83)\end{array}$ & $\begin{array}{l}-0.636 \\
(-3.08)\end{array}$ \\
\hline elect $_{i t}$ & $\begin{array}{l}-1.031 \\
(-3.29)\end{array}$ & $\begin{array}{l}-0.608 \\
(-2.59)\end{array}$ \\
\hline left $t_{i t}$ & $\begin{array}{l}0.002 \\
(0.61)\end{array}$ & $\begin{array}{l}-0.001 \\
(-0.20)\end{array}$ \\
\hline$E U_{i t}$ & $\begin{array}{l}5.391 \\
(3.00)\end{array}$ & \\
\hline $\begin{array}{l}\text { Time dummies } \\
\text { (p-value) }\end{array}$ & $\begin{array}{c}\text { yes } \\
\text { (time demean) }\end{array}$ & $\begin{array}{c}\text { yes } \\
\text { (time demean) }\end{array}$ \\
\hline Time trend & no & no \\
\hline No. instrum. & 29 & 28 \\
\hline Hansen (p-value) & 0.762 & 0.657 \\
\hline $\operatorname{AR}(2)$ test ( $\mathrm{p}$-value) & 0.290 & 0.815 \\
\hline No. of countries & 26 & 25 \\
\hline No. of obs. & 347 & 275 \\
\hline
\end{tabular}

Notes: t-values in parentheses if not stated otherwise. 


\section{References}

Arellano, M. AND S. Bond (1991): "Some tests of specification for panel data: Monte Carlo evidence and an application to employment equations," The Review of Economic Studies, 58, 277-297.

Armingeon, K., M. Gerber, P. Leimgruber And M. Beyeler (2008): "Comparative political data set 1960-2006," Institute of Political Science, University of Berne.

BÄHR, C. (2008): "How does sub-national autonomy affect the effectiveness of structural funds?," Kyklos, 61(1), 3-18.

Beugelsdijk, M. AND S. EiJfFinger (2005): "The effectiveness of structural policy in the European Union: An empirical analysis for the EU-15 in 19952001," Journal of Common Market Studies, 40, 37-51.

Blundell, R. AND S. Bond (1998): "Initial conditions and moment restrictions in dynamic panel data models," Journal of Econometrics, 87, 115-143.

Bohn, H. (1998): "The behaviour of U.S. public debt and deficits," Quarterly Journal of Economics, 113, 949-963.

Bond, S., A. Hoeffler And J. Temple (2001): "GMM estimation of empirical growth models," Nuffield College Economics Working Paper, 2001-W21.

Bouvet, F. (2005): "European Union regional policy: Allocation determinants and effects on regional economic growth," mimeo.

Bruno, G. (2005a): "Approximating the bias of the LSDV estimator for dynamic unbalanced panel data models," Economic Letters, 87, 361-366.

(2005b): "Estimation and inference in dynamic unbalanced panel data models with a small number of individuals," CESPRI Working Paper, Universita Bocconi-CESPRI, 165.

Cunaresma, J., D. Ritzberger-Grünwald And M. Silgoner (2008): "Growth, convergence and EU membership," Applied Economics, 40(5), 643656 .

DAll'erba, S. AND J. Le Gallo (2007): "The impact of EU regional support on growth and employment," Czech Journal of Economics and Finance, 57(7), $325-340$.

Driscoll, J. AND A. KRAAY (1998): "Consistent covariance matrix estimation with spatially dependent panel data," The Review of Economics and Statistics, $80(4), 549-560$.

ECKEY, H. AND M. TüRK (2006): "Convergence of EU-regions. A literature report," University of Kassel, Discussion Papers in Economics, 80/06.

Ederveen, S., H. de Groot and R. Nahuis (2006): "Fertile soil for structural funds? A panel data analysis of the conditional effectiveness of European cohesion policy," Kyklos, 59, 17-42. 
Ederveen, S., J. Gorter, R. De Mooij And R. Nahuis (2002): Funds and games. The economics of European Cohesion Policy. The Hague.

EgGert, W., M. von Ehrlich, R. Fenge and G. KÖNig (2007): "Konvergenzund Wachstumseffekte der europäischen Regionalpolitik in Deutschland," Perspektiven der Wirtschaftspolitik, 8(2), 130-146.

Esposti, R. And S. Bussoletti (2008): "Impact of Objective 1 funds on regional growth convergence in the European Union: A panel-data approach," Regional Studies, 42(2), 159-173.

European Commission (2004): "Capping of ressources," Working Document of the Commission Services, Multiannual Financial Framework 2007-2013, Fiche no. 27. embourg.

(2007): Cohesion policy 2007-13 - Commentaries and official texts. Lux(2008): EU budget 2007 - Financial report. Office for Official Publications of the European Communities, Luxembourg.

Hagen, T. And P. Mohl (2010): "Econometric evaluation of EU Cohesion Policy - A survey," in International Handbook of Economic Integration, ed. by M. Jovanovic. Edward Elgar, Cheltenham.

Heinemann, F., T. Hagen, P. Mohl, S. Osterloh and M. Sellenthin (2009): Die Zukunft der EU-Strukturpolitik, ZEW Wirtschaftsanalysen. Nomos Verl.-Ges., Baden-Baden.

Hoechle, D. (2007): "Robust standard errors for panel regressions with crosssectional dependence," The Stata Journal, 7(3), 281-312.

Judson, R. AND L. Owen (1999): "Estimating dynamic panel data models: A guide for macroeconomics," Economics Letters, 65(9-15).

Kiviet, J. F. (1995): "On bias, inconsistency, and efficiency of various estimators in dynamic panel data models," Journal of Econometrics, 68, 53-78.

Lucchetti, R., L. Papi And A. Zazzaro (2001): "Banks' inefficiency and economic growth: a micro-macro approach," Scottish Journal of Political Economy, $48,400-424$.

Maddala, G. And S. Wu (1999): "A comparative study of unit root tests with panel data and a new simple test," Oxford Bulletin of Economics and Statistics, 61, 631-652.

Mehrotra, A. And T. VÄLILÄ (2006): "Public investment in Europe: Evolution and determinants in perspective," Fiscal Studies, 27(4), 443-471.

Mohl, P. And T. Hagen (2008): "Does EU Cohesion Policy promote growth? Evidence from regional data and alternative econometric approaches," $Z E W$ Discussion Paper, 08-086. 
NiCKELL, S. (1981): "Biases in dynamic models with fixed effects," Econometrica, 49, 1417-1426.

Nunziata, L. (2005): "Institutions and wage determination: A multi-country approach," Oxford Bulletin of Economics and Statistics, 67(4), 435-466.

Persson, T. and G. Tabellini (2000): Political economics: Explaining economic policy. MIT Press, Cambridge (MA) and London.

Roodman, D. (2009a): "How to do xtabond2: An introduction to difference and system GMM in Stata," The Stata Journal, 9(1), 86-136.

(2009b): "A note on the theme of too many instruments," Oxford Bulletin of Economics and Statistics, 71(1), 135-158.

Shi, M. And J. Svensson (2003): "Political budget cycles: A review of recent developments," Nordic Journal of Political Economy, 29(67-76).

Sото, M. (2006): "System GMM estimation with a small number of individuals," Mimeo.

Tabellini, G. And A. Alesina (1990): "Voting on the budget deficit," American Economic Review, 80(1), 37-49.

White, H. (1980): "A heteroskedastic-consistent covariance matrix estimator and a direct test for heteroskedasticity," Econometrica, 48, 817-838.

WindmeiJeR, F. (2005): "A finite sample correction for the variance of linear efficient two-step GMM estimators," Journal of Econometrics, 126(1), 25-51. 